\title{
Mommsen's Roman Criminal Law ${ }^{1}$
}

JURISTS and historians are alike agreed that we have no such thing as a science of Roman criminal law. That this work may fill the gap, so often recognised, is my wish, and to a certain extent my bope.

So writes Professor Mommsen in the first lines of this great work, extending over a thousand pages, and dealing with a subject which bristles with problems and difficulties. The hope is expressed with a modest pride, justified by a lifetime of scholarly labour, and I believe that the verdict of the world of letters, which is without appeal except to posterity, will decide that this hope has been fulfilled. Future labourers will take Mommsen's work as a basis and starting point for their own, and though the superstructure may be modified the foundation is destined, if prophecy be permissible, to remain.

It is difficult to say whether the work is rendered more or less useful for its purpose by the circumstance that this book is purely constructive and not critical. Mommsen's justification for his method must be given in his own stately and pathetic words.

I have attempted to deal, so far as may be, exhaustively with the ancient authorities: to do the same with the modern writers on the subject was beyond my power. Impossibility is a good plea at law. If controversial matters had been discussed, the book would doubtless have avoided many errors and have escaped many omissions: it would often have proved more satisfying on particular points. But for one thing it must have been at least doubled in length, whereas, even as it is, it may well be considered too long by the reader, as it is by the writer. Still more decisive is the consideration that it would certainly never have been finished. Everything has its time, and man among the rest. The writer must be permitted to reckon with the span of life that remains for him, which may well be a limited one.

We may be thankful for a resolution which has prevented this book from being relegated to the limbo of unfinished works, and accept without a murmur the limitations which the conditions of the task have imposed on the author. These limitations, however, seriously increase the difficulties of the reviewer, whose work is

' Römisches Strafrecht, von Theodor Mommsen. Leipzig, 1899. 
necessarily critical. When one finds deductions from the evidence, propounded in contradiction of those which have been commonly regarded as part of the stock in trade of a teacher of Roman history, it would be a great help to be able to refer to the arguments of modern scholars who have upheld the opposite side. I can only follow in this respect the author whom I am reviewing, and support any doctrines as to which I venture to differ from him by arguments drawn from the evidence, careless, except where memory happens to supply the source, if these arguments were originally suggested to me by the works of other modern authors, or, as I believe is frequently the case, by the earlier writings of Mommsen himself.

It will not be necessary to dwell on Mommsen's definition of the nature and sphere of the criminal law. Suffice it to say that he rejects for the purposes of this work the division, suggested to the jurists by the differences of procedure, between ' crimes,' which the state punishes on its own account, and 'torts,' which it leaves the injured person to prosecute or not, as he pleases.

The fundamental characteristic (he says) of a moral law broken, and a reparation prescribed therefor by the state, unites the two spheres in an essential identity, and the difference, whether this reparation is realised in a suit at public or at private law, appears in comparison superficial and accidental. ${ }^{2}$

The general distinction between Recht and Prozess, or, as English jurists say, of 'substantive' and 'adjective' law, is in like manner rejected, as giving no suitable basis for the order of this book.

Such a division of the subject (says Mommsen), besides being questionable in itself from a scientific point of view, is utterly unsuited to criminal jurisprudence, and has contributed not a little to the poverty of the literary work on that subject. ${ }^{3}$

The details of procedure occupy one book (the third) of the five into which this volume is divided; but the procedure itself forms in fact an element in the discussion of the nature and origin of the Roman criminal law, of the officers of justice, of the several crimes, and of the punishments, which form the subjects of the other books. Without attempting to enter into the question of scientific order I will only say here that the arrangement which Mommsen has adopted justifies itself in practice, and makes it comparatively easy to find one's way through a thousand pages on a subject of great complexity.

In tracing the origins of the Roman criminal law Mommsen recognises five main sources-religious obligation, the power of the head of a household over his children and dependents, the self-help practised by each householder in defence of himself and his, the 
power of a commander-in-chief to punish offences against military discipline, and finally the right of coercitio, by which the magistrate at home compels the obedience of the citizens. It will be convenient to take these in order.

Religion was prevented from becoming a very fruitful source of law among the Romans by the severance, which they fortunately at an early tate effected, between the secular functions of the magistrate and the spiritual judgments of the priesthood. In Clodius's case, for instance, when the pontiffs have pronounced that the invasion of the mysteries of the Bona Dea was nefas, the consuls and senate are practically bound to take further notice of it; but the pontiffs themselves have nothing to do with trial or punishment, nor the consuls with religion. The religious obligation to purge sin from the community by treating the guilty person as a scapegoat " is rather a motive underlying the action of the state in the matter of criminal law than a source of any power to punish. Nevertheless the motive has left its traces on the forms of punishment which it bas pleased the state to prescribe. We may hesitate indeed to agree with Mommsen's hypothesis (see below, p. 245) about the connexion of the primitive form of execution with the ritual of sacrifice, but there is no question that sanctio, the most general expression for the penalty by which any law is enforced, had originally the same meaning as sacratio, ${ }^{5}$ the devotion of the offender's life and goods to some god; and specific instances ${ }^{6}$ of this, as the punishment for certain offences, are to be found in the Twelve Tables and in other early laws.

The discussion of household discipline begins with what may seem an exaggerated appreciation of its importance in the development of the criminal law. We read ${ }^{7}$ that

Roman theory at least starts with an original unqualified power of punishment on the part of the magistrate, completely similar to that of the master of the household, and all laws are, just what the master's regulations are in the house, rules laid down for itself by the state, which the community has made and can unmake, and which bind the members of the body unconditionally, but bind the state itself only till further notice. As he who wishes to know the stream must never forget its source, so the Roman criminal law can be understood only on the basis of household discipline.

I am inclined to think that as a matter of fact this is a case of

- It was doubtless for this reason that the consular M. Claudius, surrendered in 236 в.c. to the Corsicans to atone for a breach of international law, was brought back to Rome, when the enemy refused to accept him, and strangled in the prison (Val. Max. vi. 3, 3), apparently without being allowed the right of appeal (see Strafrecht, p. 46).

${ }^{3}$ Strafrecht, p. 901 . See also below, p. 227.
"Strafrecht, pF. 822, 903.
Ibid. p. 16. 
resemblance, not of origin. No Roman writer, ${ }^{8}$ so far as I know, has ever attributed the patria potestas either to the magistrate, whether king or consul, or to the sovereign people itself, and there is no trace of the powers exercised by the state authorities developing out of those exercised by the head of a family. The connexion which he assumes between the two does not lead Mommsen far astray, for he adds shortly afterwards-

Jurisdiction rests on the power of the community over the individual, and this power differs, as the tree differs from the seed, from that of the owner over his property, not absolute and unlimited, like the latter, but defined and limited by the rules of law. Further the individual, who is subject to the household power, if he offends, can be called to account either by the master of the house in virtue of his ownership or by the state in virtue of its supreme power; and this household procedure not only does not itself belong to the criminal law, but can never have been transferred to it, both because the contrary nature of the two must be clearly maintained and because the law of the master of the house partly overlaps and partly supplements the criminal.law of the state."

We may object to the metaphor of the seed and the tree, but in other respects the account given of the two authorities could not be more true or more forcible.

There are, however, two cases in which household law comes into interesting relations with the state. The first is the jurisdiction exercised by the pontifex maximus over the daughters of the community, the vestal virgins. This is in all respects a case of patria potestas, with its consequent right of personal chastisement and its fullest powers of life and death. Here, in strictest conformity with the principles laid down in the paragraph just quoted, the state as a political power claims a jurisdiction concurrent with that of the head of the household. ${ }^{10}$ In the year 114 B.c. two vestals who had been already acquitted by the pontiff were again arraigned before a tribunal instituted by a special law of the people, and both were condemned. It is probable, though not certain, that the full penalty was exacted; at any rate the vestals were not allowed to play off the one jurisdiction against the other. Another very curious point is that not only the vestals themselves but their paramours were subject to the pontifical jurisdiction. If condemned of incest by the pontiff they were scourged to death without being allowed the right of provocatio. Mommsen was formerly ${ }^{11}$ of opinion that this is a survival of the right of avenging his honour possessed by a householder against the seducer of his daughter. $\mathrm{He}$ is now disposed to consider that this jurisdiction over the man

* In a passage quoted below (p. 224) Mommsen seems to imply the contrary, but he does not support his thesis by any references. The very basis of the 'domestica disciplina,' the right of ownership, is wanting to the state.

- Strafrecht, p. 17.

10 Ibid. p. 197.

"See Staatsrecht, ii'. p. 56, n. 5 . 
is of comparatively late origin and depends on a definite law of the people. ${ }^{12}$

The second case in which household discipline appears in connexion with the ordinary law is that of women convicted of criminal acts. Over and over again we find the actual execution of punishment, capital or otherwise, committed to the relatives of the culprits instead of being carried out by the servants of the state. The important point is that this occurs not only with those who are under the potestas of father or husband (in such a case the persons quorum in manu essent have a clear right to deal with them), but with women who are sui iuris, and are nevertheless put to death or banished by cognati or propinqui..13 Mummsen considers this to be a survival from a supposed 'original order of things,' according to which a woman always and necessarily remained under patria potestas. If there were neither father nor husband to claim it, the absolute rights over person and property passed (such is the hypothesis) to the gens, and the primitive tutela gentilium is set down as probably equivalent to the manus, with the consequence that a woman under this system could never be sui iuris. This is a hard saying, and is certainly not to be justified by straining (as Mommsen does) ${ }^{14}$ the words of so easy-going a writer as Livy (xxxiv. 2, 11): Maiores nostri feminas voluerunt in manu esse parentium, fratrum virorum. In Roman law, as we know it, tutela is possible only in case of persons sui iuris ; its intention is to give to persons otherwise capable of legal acts, but of weak age or sex, protection from the consequences of acts by which they would, but for such protection, be bound; such acts are to be valid if, and only if, they have been confirmed by the consent of a guardian. A person alieni iuris, a slave, a son, or a daughter, is essentially incapable of legal acts, and the notion of protection in their exercise becomes absurd. Thus the two conditions are mutually exclusive; and that tutela is in any case equivalent to manus is a proposition which could only be accepted on the strongest evidence. In this case the evidence is not forthcoming. We know that as early as the law of the Twelve Tables a woman was capable of holding property, and that on the death of a father the daughters who were at the time under his patria potestas inherited their share of the property equally with their brothers; it seems to follow that they became persons sui iuris and consequently calling for guardianship. Mommsen's hypothesis relates, of course, solely to a primitive, pre-historic era. As he himself says in a later passage,

12 He rests this belief on Festus's statement (s.v. Probram): 'Probrum virginis Vestalis ut capite puniretur, vir, qui eam incestavisset, verberibus necaretur ; lex fixa in atrio Libertatis cum multis aliis legibus incendio consumpta est, ut ait Cato' (Strafrecht, p. 20).

${ }_{13}$ The two categories are distinguished in the case of the Bacchanalian women (Livy, xxxix. 18, 6).

istrafrecht, p. 18. 
the woman under potestas enjoys the protection of a free-woman as against third parties, but, like a slave, is treated by her master as his property. If he kills her the act does not in itself fall under the category of murder. It has been shown that in historical times this holds only in case of the paternal or marital power. It may have held in the earliest times in case of the gentile guardianship over the unmarried fatherless woman. But the universal servitude of women has disappeared from the legal system by the time when we have any knowledge of it. ${ }^{15}$

The hypothesis as to the primitive state of things is required then only to explain the custom as regards the execution of female criminals, with which we started. It seems a simpler explanation if we suppose that the officers of the state, from motives of decency, preferred that women should not be put to public execution or thrown into the common gaol, and that accordingly they not only called on the father or husband, where there was one, to exercise his power in their stead, but that even in case of women sui iuris they selected an idoneus anctor supplicii (to use Livy's description) from among the relatives, and delegated to him a power of execution which he did not possess in his own right.

Early in the discussion of military law, which forms the subject of the chapter following that on household discipline, we find one of the most interesting and suggestive passages ${ }^{16}$ in the whole work. I propose to quote this at length. Mommsen first points out that tradition accepted the unrestricted power, civil and military, exercised by the magistrate of historical times outside the walls (imperium militiae) as the type of magisterial power in its essence, and represented that power as having been gradually limited inside the walls by various restrictions (mainly those of time, of collegiality, of fixed rules of procedure, and of appeal to the people), which constitute the conditions under which the imperium domi is exercised, and on which the later order of the state, and especially the criminal law, depends. He proceeds-

It is obvious that this constructive theory of law cannot be regarded as historical. It originated partly from the transference of household discipline to the ordering of the state, since the relations of king and citizens were assimilated to those of the house master and his subjects, ${ }^{17}$ partly from ascribing universality to the later military law. It scarcely realises the full and true picture of the facts. We may rather suppose that the severance between the magisterial power inside and outside the walls is as old as the walls themselves, and that the original power of the ruler was essentially limited to the external sphere, while inside the walls anarchical independence held the first place, and each householder had to look mainly to himself and his followers-that is to say, to self-

is Strafrecht, p. 617.

16 Ibid. pp. 27, 28.

i: This is very questionable. See above, p. 222. 
help. It is nevertheless true that, carried out to the uttermost, such anarchical independence is not consistent with the continuance of the community, and that we should not ascribe to the Roman king the character of merely a captain of the host. The members of the community found themselves assembled to repel a foreign aggressor with their united strength, and helped one another in like manner in case of fire. For such defence and such help they set a foreman at their head. It is a long way from this primitive commonwealth, wherein the lord of the community leads the citizens outside the walls to ward off raiders or to raid themselves, and inside the walls, on danger of fire, appears at the burning, down to the present development of the state, with the public training of each citizen to the trade of arms and the mighty conception of the common participation in every suffering and sorrow that affects the individual-a long way, just as it is a long way from the twelve beadles who cleared the street before the Roman chief magistrate to the standing armies of to-day. But on this long way the development of the state has trodden in the footsteps of the Roman commonwealth.

The historical contrast between the self-help of the citizen and the discipline of the magistrate is admirably put, and no less sound is the conclusion that it is necessary to pay most attention to the latter. It is a more fruitful procedure, when we are analysing the institutions of historical times, to keep before our eyes the traditions in which the Romans themselves believed, and which therefore determined their action, than to lay too much stress on primitive facts, which had ceased to influence later generations. Mommsen is therefore justified in his method, which bases the criminal law, as the Romans would have based it, on the initial power of the magistrate, limited indeed by successive enactments, but subsisting throughout as the mainspring of action. Still there are certair cases in which self-help remained a living tradition, and its survivals are traceable to an extent which gives it a fair title to a place among the sources of the criminal law. It will be more convenient in this place to treat self-help first and then to come back to the magisterial authority at home and abroad.

The law of the Twelve Tables stereotypes procedure at the moment of transition from the rule of private vengeance to that of state adjudication, and hence it comes that theft and some other offences, which in modern systems fall under the domain of public law, remain the subject of private suits in Rome.

The magistrate ${ }^{18}$ here interposes between the contending parties as a mediator : on the one hand be settles or causes to be settled the question of fact; on the other hand, when a wrong has been proved, he either gives self-help its course or enjoins the injured party to renounce it on consideration of receiving compensation. . . The execution, again, in such cases differs from that against public crimes, 
inasmuch as against the crime prosecuted by private suit, when self-help is permitted, the aggrieved party himself becomes the executioner.

In the rare cases where the penalty of death follows condemnation in such private suits-the most notable are those of false witness and of theft committed by a slave caught red-handeddeath was inflicted by the primitive method of Lynch law, and the offender was flung from the Tarpeian Rock, 'the usual form of legal execution where infliction by a magistrate is excluded.' 1" In the case of personal injuries, again, we find ${ }^{20}$

When the injured person demands it, just as the so-called courts of honour, in the rebarbarising of our nation which is now beginning, license the duel, so the Roman courts of justice granted leave on the part of the state for the aggrieved to proceed against the aggressor by way of self-help on the principle of 'Be done by as you did'-Si menbrum rupsit, ni cum eo pacit, talio esto.

Thus the criminal law still to a great extent ' rested on the blood revenge.' ${ }^{21}$ But such practice did not long survive the legislation of the decemvirs. Either the state itself undertakes the punishment of crimes (there are notable instances even in the Twelve Tables), or in the development of the private criminal suit 'self-help ${ }^{22}$ is completely set aside, and every wrong is subject to the compulsory compensation prescribed by the state for the outraged person.' Mommsen points out ${ }^{23}$ that such composition must needs have become universal, as the fulfilment of the lex talionis by private individuals became not only more at variance with the social order of a civilised state, but likewise more difficult for the private person to secure. The older law seems to have been si quis membrum rupit aut os fregit, talione procimus cognatus ulciscitur; but this was laying a hard task on the injured man's kin, and we soon find the case arising that the offender may refuse to offer suitable compensation and jet be strong enough to save his own limbs; in that case the law again steps in and fines him a definite sum: si r'us qui depecisci noluerat iudici talionem imperanti non parebat acstimata lite iudex hominem pecuniae damnabat. ${ }^{24}$ After this, if he does not pay, he is, of course, liable to arrest and addictio, like any other debtor. There seems to be no tradition of any punishment of maiming being carried out in republican times by the judicial authorities themselves, ${ }^{25}$ or even of assistance given by them to the private man in carrying out bis authorised vengeance. 'The result of these changes in judicial practice is well summed up by Mommsen. ${ }^{26}$

\footnotetext{
19 Strafrecht, p. 931. 20 Ibid. p. $62 . \quad 21$ Ibid. p. 940.

$=$ Ibid. p. 905 . $\quad 2$ Ibid. p. 802 .

-t See ibiul. p. 802 , notes 2 and 4 (referring to Gellius, xx. 1, 38).

s Strafrecht, p. $982 . \quad{ }^{20}$ Ibid. p. 941.
} 
From that time forward capital punishment by private suit is set aside and never reappears. The conception of the ransom money, which has from the first entered with effect into the procedure for crimes against individuals, henceforth reigns supreme in this sphere.

Those crimes which the Romans desired to punish otherwise than by pecuniary damages were removed by them to the sphere of public justice (see below, p. 238). As Mommsen says in another sentence, ${ }^{27}$ 'this practically comes to the abolition of the blood feud.'

We shall find appeal made to self-help later on in the ignis et aquae interdictio of the final period of the republic, and especially in the proscriptions in which private men were stimulated by the offer of blood money to wreak the vengeance of a party on its opponents. But, apart from such abnormal developments of the doctrine of outlawry, the self-help of private members of the community is from very early times sometimes invoked in redress not only of private but of public wrongs. The most notable instances of wrongs to be so punished are the attempt, whether successful or not, to restore the kingship, and the violation of the sanctity of a tribune. The two instances can hardly be treated apart, ${ }^{28}$ though they differ in some incidental points. In both cases we find the obligation which lies on the people to prevent these crimes confirmed by an oath, "which gives the stamp of unalterableness to the decree,' ${ }^{29}$ and in both cases the penalty is threatened in the form of a sacratio of the life and goods of the offender. Mommsen rightly protests ${ }^{30}$ against the doctrine that sacratio necessarily excludes the trial and sentence of the offender. This is absolutely disproved by Festus's definition, Homo sacer is est quem populus iudicavit ob maleficium. Indeed, as we have already seen, sacratio includes the sanctio which prescribes the death of an offender found guilty after a trial in due course of law. But we learn from Livy (iii. 55, 7) that the Roman jurists recognised that the sacrosanctitas of the tribune rested on something more specific than the sacratio $^{31}$ by law of any offender against his person. At the first institution of the office the decrees of the plebs had not the force of law, and some basis of inviolability outside the law had to be found for the tribunes. The consular law of Valerius and Horatius, passed after the fall of the decemvirs, gave to the tribunate the legal defence which it had at first wanted. Logically, perhaps,

27 Strafrecht, p. 941. 23 Ibid. p. 552. ${ }^{20}$ Ibid. p. $553 . \quad{ }^{30}$ Ibid. p. 901, n. 3.

31 Ibid. p. 901, n. 5. Mommsen refers us to his Staatsrecht, $\mathrm{ii}^{3} .303$, n. 2, for his brilliant explanation on the same lines of a difficult and corrupt passage of Cicero (Pro Balbo, 14, 33). Whatever may be the precise emendation required for the text, I think that there can be little doubt that he is right as to the sense - vamely, that 'sacrosanctitas' may be predicated either from the nature of the penalty attached or from the confirmation of that, which is decreed, by an oath binding on the people. 
this tardy recognition ought to have sufficed for all purposes, ${ }^{32}$ but in fact the plebs did not on that account renounce its older method of enforcing respect. This method is the primitive self-help.

'The sacrosancta potestas of the tribune,' says Mommsen, 'is originally a euphemism for revolutionary self-help ; ${ }^{33}$ and again-

In place of the death penalty prescribed by law for the violation of the magistrate ${ }^{34}$ we find the political self-help, confirmed by oath, which intervenes whenever the law is exhausted, especially in case of the ban laid on the kingship or any equivalent power. ${ }^{35}$

In his latest work Mommsen has presented the same doctrine in sufficiently clear, if not in equally striking, form. 'The plebeian constitution,' he says, ${ }^{36}$ ' is nothing more than formularised revolution, and revolution protects itself even when the protection is not formulated ;' and again-

With respect to legal protection of the tribune and of plebeian privilege generally, the confirmation of the law by the permission of popular execution is asserted with especial emphasis ; and this is natural enough, since legal magisterial execution was not applicable to these essentially revolutionary ordinances, and these same private tribunician ordinances, without such a rerolutionary appeal to the self-help of the plebeians, would have been a dead letter. ${ }^{37}$

In the few cases in which the punishment of death is stated to have been actually inflicted or attempted by a tribune the method is that of popular execution; the tribune has no lictors or axes and can only throw the offender from the Tarpeian Rock. ${ }^{38}$ As a general rule his sentences allow an appeal to the comitia: in case of fines he himself convokes the plebs to hear the appeal, and in case of capital sentences 'he aslis the practor urbanus for a day of the comitia centuriutic.' Such is the procedure against the censors, Claudius and Gracchus, who were adjudged guilty of perduellio by a tribune for supposed contempt of his office in the year 169 B.c. The censors were finaliy acquitted by the people, but if they had been condemned they would, like other criminals of that period, bave escaped death by exile. ${ }^{39}$ Sometimes, however, we hear of a far sharper and shorter method. In the year 131 B.c. a tribune, Atinius Labeo, actually laid hold on the censor Metellus (again for contempt) and dragged him to the top of the Tarpeian Rock.

32 Staatsrecht, $\mathrm{ii}^{3} .302$.

Ibid. $\mathrm{ii}^{3} .287$.

24 I.e. the 'patricius magistratus,' the 'magistratus populi llomani.'

ss 'Or any equivalent power.' Mommsen's words are justified by the passage which he quotes (Strafrecht, p. 551, n. 1) from Cicero, Dc Rep. ii. 27, 49: 'Nostri omnes reges vocitaverunt qui soli in populo perpetuan potestatem haberent.'

36 Strafrecht, p. 553, n. $4 . \quad$ "7 Ibid. p. 937.

is Ibid. p. 933 .

39 Gracchus saved his fellow censor by swearing that 'si collega damnatus esset, non expectato de se iudicio, comitem exilii eius futurum ' (Livy, xliii. 16, 15). 
The execution was prevented by the auxilium of another tribune, ${ }^{40}$ the right of Labeo being thus, as Mommsen remarlis," 'at once acknowledged and frustrated by intercession.' In the reported cases the self-help is always the work of the aggrieved tribune himself, or of his colleague. There is no recorded instance of the private plebeian having ever been called upon, in obedience to his oath, to avenge an outrage on a tribune; ${ }^{42}$ but the knowledge that such vengeance would be forthcoming, if necessary, was sufficient to enable the tribune to act, as Mommsen says," "without instruments by the grip of his own hand, to which, in case of any opposition, the inviolability of his person gave the necessary power.' Cicero has this ultimate sanction in mind when he illustrates ${ }^{44}$ the unfairness of the contest between Clodius and himself, tribuniciique sanguinis ultores esse praesentes, meae mortis poenas iudicio et posteritati reservari.

The passage last quoted indicates pretty clearly that condemnation before a legal tribunal is not a necessary preliminary to the self-help of the plebs. On this point the utterances of Mommsen are somewhat wavering. In one passage ${ }^{45}$ he seems to suggest a negative answer to the question "whether the tribune is legally entitled to proceed without further ado to such executions, a doctrine which, for the matter of that, was never fully acknowledged, and only appears as the party claim of the advanced democracy;' and to give the preference to the other alternative-' or whether, as after the conclusion of the struggle of the orders was the recognised right, he required confirmation by the people before he executed capital punishment;' and in the 'Staatsrecht' 46 we read-

In its better times the democracy certainly treated every attack on the tribunate as a crime worthy of death, but did not sacrifice to it the dearest right of the commons, the right of appeal ; and the usurpation obviously never became recognised law. According to the theory of the later democracy the slaying of him who violated a tribune was permitted to every citizen without judgment and without law, just as the slaying of him who aspired to kingly power. Whoever acted on this doctrineand no instance is recorded-could call his deed an execution of the law only in the sense in which Brutus and his fellows claimed to have executed the law on the dictator Caesar.

We get a somewhat different impression from a passage in the first book of the work now under review.

The tribunician right over life and death rests not on the same ground as that of the patrician magistrate, but on the constituent

40 Pliny, Nut. Hist. vii. 44, 143 : 'Quum resistendi sacroquesanctum repellendi ius non esset, virtutis opera et censurae periturus, aegre tribuno qui intercederet reperto, ipso a limine mortis revocatus.'

1 Strafrecht, p. 47.

13 Tbid. p. 932.

is Strafrecht, p. 932.

12 Ibid.p. 937.

"Post Red. in Sen. 13, 33.

16 Staatsrecht, ii ${ }^{3} .305$. 
ordinances of the plebs, on the power, namely, similar to that of the patrician imperium, thereby guaranteed to its leaders and afterwards recognised by the law. Now, since the right of the patrician consuls over the life and death of the citizens was by the Valerian law bound up with the assent of the populus, it was only proper for the representative of the plebs to connect their similar power with the consent whether of the plebs or, later on, of the whole people. But strictly speaking it might be said that the tribunes possessed a right, similar to the original right of the consuls, and that they were not limited, like the latter, by the Valerian law. In fact we know of one fully accredited historical instance of tribunician action, clearly justified by the letter of the law, wherein trial and appeal were excluded, and the tribune treated the Roman citizen as if he were a foreign criminal. ${ }^{47}$

The instance, of course, is that of Labeo and Metellus, and in reference to the same case Mommsen says later on, "The tribune just punishes the perduellis as such:'

On the whole the judgment indicated in the passages last quoted may be taken as the sounder of the two. We have seen that the Romans of Cicero's time allowed the doctrine, even in its extreme form, as justifying the action of private men; we have seen that its maintenance was necessary for the tribunate in its inception; and this being so, the facts that the doctrine was very liable to abuse, and that the practice of the middle republic allowed it to fall into desuetude, do not justify us in ascribing the doctrine itself to a party theory of the extreme democrats in the last age of the free state.

The case of the violator of the tribunician sanctity and that of the usurper of monarchical power are, as Mommsen clearly sees, precisely parallel; only with the latter the necessity of the case shows us more distinctly what was the intention of the legislator. Mommsen ascribes the current and obvious interpretation in this case too to 'the party doctrine of the republican legitimists.' In his discussion of it ${ }^{49}$ he seems to me to carry too far the distinction between the oath -

in which might be found, not indeed the legal, but the moral and political obligation to treat such a king as equivalent without more ado to a public enemy-

and the sacratio, of which he says

that it is nothing more than a threat of capital punishment, the execution of which must be preceded, even in this case, by a legal conviction.

It seems more correct to say that the sacratio 'legally' permitted that to which the oath 'morally or politically obliged.' When the Romans laid down concerning the monarch, eum ius fasque esset occidi, nere ea caedes capitalis noxae haberetur, ${ }^{50}$ they cannot possibly

\footnotetext{
'7 Strafrecht, p. 46. $\quad$ ts Ibid. p. 553, n.5. 19 Ibid.p. 552 . so Livy, iii. 55.
} 
have intended the futility of granting the slayer immunity only on a condition so impossible as that of the formal trial of the usurper. How could he be brought to trial? "When, it succeeds no man dare call it treason.' This is so obvious that I thinl that the proposition that the Roman law authorised tyrannicide would never have been disputed, if this law had not unbappily served to supply a doctrinaire motive to the assassins of Caesar. Nommsen scorns to take refuge in the suluterfuge that Caesar was not a king. For the rest it would have been better if he had been contented to take up the impregnable position that assassination as a political weapcn is never to be justified, and that $九$ law or oath which prescribed it to all future generations ought never to have weighed in the minds of persons professing to be serious statesmen. Discussions as to its binding chas:acter should have been left to Roman antiquarians and Greek philosophers.

It is time to return to the discussion of the impcrium of the magistrate, by means of which the collective force of the community is brought to bear upon the individual, in antithesis to the self-help which brings the force of one citizen to bear on another. It is manifest that such a gathering up of force in the hand of a leader is necessary for the command of soldiers on a warlike expedition, and accordingly the absolutism of the commander is accepted by the Romans as the lype of the original and unfettered power of the magistrate. This unfettered power extends in historical times far beyond the nar'ow limits which an Englishman is used to place on the phrase 'military law' and it represents the rule under which, at one time, all the inhabitants of the western world, excepting a small privileged class, lived and suffered. For the Romans militiae 'on service' is a locative opposed to domi, and includes the whole world less the city of Rome. The imperium militiae is exercised not only on the soldiers, legionary or auxiliary, but on the whole population (except so far as a definite treaty may give to this or that allied territory a precarious exemption), and not only on the subjects but on the Roman citizens who venture outside the charmed circle of the walls of Rome. In this sphere there exists, no doubt, the concurrent jurisdiction of the native authorities of subject states, but the Roman magistrate is, like the English crown, 'over all persons and in all causes supreme,' and in his supremacy the distinction, so far at any rate as criminal law is concerned, between military and civil jurisdiction, though in practice it can never have been wholly disregarded, is legally non-existent. The imperium militiae explains ${ }^{\text {it }}$ not only exactions from a peaceful town, such as Livy ${ }^{52}$ ascribes, to the consul of 173 B.c. at Praeneste,

il Strafrecht, p. 29 , n. 2 .

32 Livg, xlii. 1. 'That lioman citizens,' Mommsen iLdds, were not treated in 
but the intervention of the senate (that is to say, of the consuls on the advice of the senate), described by Polybius, ;3 ' in cases of crime demanding public supervision, as treason, conspiracy, poisoning, and assassination thoughout Italy.' Mommsen sums up the matter as follows :-

Outside the walls the state of war is legally permanent. . . Liability to military jurisdiction falls in the first place on every man serving in the Roman armies, but furthermore in point of law on every man whomsoever, without distinction of his personal rights. The extension of the discipline of the camp to Italians and provinciuls not on military service is the legal source of that abuse of the powers of magistracy of which the last two centuries of the republic more especially present us with instances unparalleled in atrocity. ${ }^{\text {.H }}$

As regards the provincials this suljection to unlimited power lasted to the end ; but as regards Roman citizens towards the end of the republic some legal limits were placed on the imperium of the magistrate even outside the walls. A lex Porcia of uncertain date is described ${ }^{5.5}$ as having 'forbidden to scourge or slay a Roman citizen.' A coin of the Porcian family, ${ }^{56}$ representing a man in armour stretching forth his hand, with the legend Provoco, shows that the law must have extended the right of appeal to the camp, and justifies Mommsen in refusing to accept literally Cicero's statement ${ }^{57}$ that the only innoration in the leges Porciae was in the sanctio; it likerise serves to correct the modern conjecture, otherwise plausible, that the alteration in military discipline for Roman citizens, which certainly took place in the latter part of the second century B.c., is to be attributed to Cains Gracchus. Mommsen further points out ${ }^{58}$ that the effect of prorocatio in this case was

like manner was due not so much to any legal prohibition as to a wholesome respect for the tribune and the comitia which awaited them in Rome.'

${ }^{4}$ Polyb. vi. 13, 4. See Strafreclet, p. 146.
ss Livy, x. 9, 4.

ss Livy, x. 9, 4. so Strafrecht, p. 31, n. 3. st De Rep. ii. 31, 54.

ss Strafrecht, pp. 32, 478. He shows that the same effect is produced on the provincial governor under the principate by the 'appeal unto Caesar.' That such an appeal is really a denial of jurisdiction is sufticiently clear from the case of St. Paul and Festus. Mommsen does not notice the serious difticulty of cases of decimation (as Plut. Crass. 10) and of Q. Cicero's threats against Roman citizens in Asia (Cic. Ad Quint. Fratr. i. 2, 6). Perhaps these last were mere bluster; and as to Crassus, be may have held that soldiers abdicated their eitizenship by leaving the post in which their country had placed them (see below, $n .69$ ). It certrinly seems strange that the action of Crassus was never questioned, whereas that of Cicero against the Catilinarians was so fiercely attacked. Mr. Greenidge (Class. Rcview, 1896, х. 226) has nttempted to solve the problem by a most interesting and ingenious hypothesis. He believes that there never was any legal limitation of the 'imperium' outside the walls, though he admits, of course, that there was a moral and customary limitation. The action of Verres when he crucified Gavius would be, according to Mr. Greenidge, cruel, wicked, and shocking, but not unlawful. This theory, however, obliges him to explain Sallust's remark about the scourging and behending of Turpilius (Jig. 69), ' Nam is civis e Latio erat,' in connexion with the proposal ascribed to the elder 
doubtless not, as in the case of the quaestors or duumvirs in the city, to submit a sentence definitely passed by the magistrate for confirmation or rejection by the comitia, but to lead the commander to refrain from passing a sentence which he could not carry out, and to content himself with arresting the offender and sending him to Rome for trial by the city magistrates, with the subsequent appeal to the people. From that time forward ' to be subject to the axe and the rods' was the description of an alien as opposed to a Roman citizen. Diodorus ${ }^{59}$ tells of an actor pleading for his life to an enraged mob of Italians at the outbreak of the Social War. 'I am no Roman, but subject, like you, to the rods. I go hither and thither through Italy, trading in pleasantries and in chase of good cheer and laughter; do not kill the swallow who is at home everywhere, to whom heaven has granted to nest unharmed about every man's house.' In the same way Pliny's well-known account ${ }^{60}$ of Balbus of Gades, sed accusatus et de iure rirgarum in eum iudicum in consilium missus, which might at first sight seem to point to a court martial hesitating whether or not to flog him, is interpreted by Mommsen, ${ }^{61}$ and I think rightly, as referring merely to the suit in which his Roman citizenship was questioned, and in which Cicero delivered the extant speech for the defence.

The unlimited jurisdiction is not confined to the region of militiae, but is exercised even inside the walls over all subjects and foreigners, and possibly over all women, ${ }^{62}$ even though citizens. The magistrate decides on his own authority, or with the assistance of such advisers as it may please him to consult, on every allegation of crime against any but the members of the privileged class of citizens of Rome. If he finds the accusation proven he scourges or puts to death according to his discretion without any possibility of appeal. Marcus Marcellus, consul in 51 B.c., scourged in this manner a misdemeanant Transpadane, simply to show that he did not agree with Caesar's contention that the colonists of the land between the Alps and the Po were Roman citizens.

The manner of death, whether outside the walls, in the camp, ${ }^{63}$ or in the subject territory, or as inflicted on the unprivileged male freeman within the city, is apparently always beheading with the axe. Beheading likewise appears as the regular method of public

Livius Drusus (Plutarch, C. Gracch. 9, 3), as meaning that Turpilius had become a Roman citizen, and thcrefore he was executed, which could not have been done if he had remained a Latin. I think that this interpretation is impossible in itself, and that it drags down with it the whole hypothesis to which it coheres.

${ }^{39}$ Lib. xxxvii. 12, 3 .

is Hist. Nat. vii. 43, 136.

61 Strafrecht, p. 47, n. 4.

${ }^{2}$ This is Mommsen's theory, but it is difficult to establish (see below, p. 252).

${ }^{65}$ The 'running the gauntlet,' 'fustuarium' (the $\xi u \lambda o \kappa o \pi i \alpha$ of Polybius), is, as Mommsen points out (Strafrecht, p. 32, n. 2), not necessarily a death sentence, tliough denth generally results. 
execution under the principate, but the sword gradually supplants the axe as the instrument. ${ }^{64}$

It remains to consider a few cases in which the unlimited power of the magistrate is exercised, even inside the walls and on Roman citizens, without the permission to appeal which commonly frustrates it. Mention has been already made of the tribunician seifhelp and of the execution of the seducer of a vestal ; the disputed cases of criminal commissions, like that against the Bacchanalians, and of the powers exercised under the scnatus consultum ultimum must be reserved for the present. Besides these we find two undoubted instances of great importance. In the first place the appointment of a dictator, before the epoch when the powers of the office were curtailed ${ }^{65}$ suspended the right of prococatio, and in the last days again of the firee state the dictator's ripullicae constituendae, Sulla and Caesar, and the triumvirs who succeeded to their power were similarly unfettered. Secondly, the chief magistrate always possesses unlimited power in dealing with military offences even within the city. Nommsen gives a number of instances, such as that of Matienus, ${ }^{60}$ who was scourged and sold as a slave for deserting the army in Spain in 188 B.c., and of the Campanian deserters ${ }^{67}$ (cices Romani sine suffragio), who seized Rhegium after the war with Pyrrhus, and on their capture were beheaded in the Roman Forum. Some objection was raised by the tribunes as to the legality of this proceeding; but they did not insist so far as to interpose their auxilium. Persons who tried to evade military duty were subject to the same summary process. ${ }^{68}$ Augustus sold as a slave a Roman linight who had maimed his sons with this object; a like punishment fell on all who neglected at the census to inscribe their names on the list of those liable to service, and Ni' Curius, consul in 275 B.c., treated in the same way the first man who failed to answer to his name at a sudden levy. Cicero justifies such exceptions to the rule that no Roman can be deprived of citizenship or liberty, on the ground that by neglecting the duties of citizens and freemen such persons have of their own action ab. dicated their status and renounced the corresponding rights. ${ }^{69}$

\footnotetext{
-1 Strafrecht, p. 9.24.

us See Festus, s.v. 'optima lex.'
}

6s Strafrecht, p. 43, n. 2. This case presents an incidental difficulty which has doubtless puzzled many, but which Mommsen has admirably solved. The Epitomator of Livy (book 55), our authority for the case, says 'accusatus est apud tribunos plebis.' It is obvious that it must be the consul, and not the tribune, who acts in a case of military discipline; but appeal can always be made to the tribunician ' auxilium,' and in this case the tribunes assembled in an administrative council, which Livy treats as a kind of court, and heard the plea of the accused before deciding not to interfere on his behalf. We may compare the case of Sthenius (Cic. in Verr. ii. 41, 100), which is so far parallel tlat here too the tribunes hold a quasijudicial inquiry in order to decide how to exercise their administrative functions.

G Val. Max. ii. 7, 15.

as Strafrecht, p. 44

- Pro Caccina, 34, 99. Mommsen (Strafrecht, p. 945, n.) finds this doctrine 'sophistic,' but it is difficult to see what other theory will cover the facts; the doctrine 
Yet one more preliminary 'question remains. That is the connexion of the criminal law' of Rome with the power of coercitio appertaining to the magistrate? 'Disobedience and rocreitio,' says Mommsen, ' ${ }^{70}$ may be looked on as correlative ideas, just like crime and punishment.' Thus coercitio in its widest sense is coincident with the whole original power of the magistrate as conceived by the Roman jurists.

The guiding idea ${ }^{1}$ is that the magistrate must retain the right of command, and that a command cannot be conceived without some means of compulsion. It is true that the magistrate ought not to use coercitio against any action which displeases him, as if he were called upon to administer censorial rebuke, but should enforce it only for the purpose of securing the necessary play for his official acts, but we cannot by any means find herein a positive limitation. Coercitio can be legally employed against every action without distinction, and, supposing that it does not overstep any limits imposed by positive legislation, it may be improper but cannot be illegal.

Outside the walls such positive limits hardly existed, and Mommsen is justified in writing, "The governor has within his province coercitio to the fullest extent, even the capital cocrcitio, over noncitizens for all times, over citizens likewise down to the age of the Gracchi ;' and again, ${ }^{72}$ 'In the coercitio of the governor is united the military and civil power of the magistracy. ${ }^{73}$

But even as against citizens inside the wall, the magistrate has a certain field for the exercise of arbitrary power, narrowed down, but not reduced to nothing, by legislative enactments. He can fine the citizen a sum ${ }^{71}$ not exceeding $30 l$. in one day; he can seize any of his chattels and publicly destroy them (concidere pignus) ; ${ }^{75}$ he can throw him into prison; ${ }^{76}$ he can order him to quit Rome (relegatio ${ }^{77}$ ); down to the time of the Porcian law he can even flog him. ${ }^{78}$ In all cases the arbitrary power is

is really the same as that of the renunciation of citizenship. by the 'perdueliis' (see below, p. 238). $\mathrm{He}$ is, no doubt, right in attributing such proceedings to coercitio rather than to criminal law.

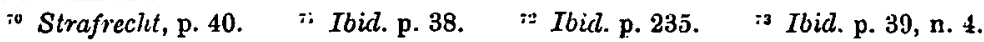

"I Ibid. p. 51. In another passage (p. 901, n. 2) Mommsen adds the confiscation of a man's property by the 'consecratio' of a tribune; but this seems to have been of doubtful validity unless ordered beforehand by the people (see Cic. De Domo, 40, 106).

is Strafrecit, p. 53.

:0 Ibid. p. 48. The 'Lex Julin de vi publica,' which forbids the imprisonment of Roman citizens, expressly excepts the case of arrest for contempt of court (ibid. p. 49, n. 2).

"Strafrecht, p. 48, n. 1. To the instances given by Mommsen may be added that of Gabinius, consul of 58 D.c., who thus expelled a Roman knight, Aelius Lamia, for upholding with too great fervour the cause of Cicero (Pro Sest. 12, 29), and that of Cicero himself, who professes to humour Catiline and give him an opportunity of joining his confederates in arms by ordering him to quit the city (Cic. Cat. i. 8, 20).

"s This is not generally recognised, but I think on the whole that Mommsen has made out his case that the 'necare et verberare' forbidden by the Valerian law must 
subject to the equally arbitrary prohibition of a colleague or a tribune.

Originally, no doubt, cocrcitio was everything: it formed, as Mommsen says, 'the germ cell of the criminal law.' 'ts 'The $i m$ perium, ${ }^{80}$ limited by law, has developed out of the original unlimited imperium; in other words, criminal law has been evolved out of coercitio ;' and again, 'We may define the original criminal iudicatio as coercitio limited by provocatio.' 81 Henceforward it is the limits and not the original power which demand most attention, and it is to them that Mommsen traces most of the machinery of the later criminal law.

The transition from the inchoate forms of justice, which we have been considering, to a regular system of criminal procedure is described by Mommsen ${ }^{82}$ in the following words :-

In the household discipline, in martial law, and in coercitio there is to be found a wrong, an investigation, an expiation of this wrong, and finally a power legally extending over the perpetrator, and exacting the expiation; in these spheres we may speak of a punishment, but not yet of a penal law. ... If the household lord, the war lord, the bearer of the civic imperium punish, yet this is always and necessarily an arbitrary act-not that what is arbitrary is always unjust. . . . The conceptions of guilt and punishment are as old as mankind, and do not first come to birth with the criminal law. . . The criminal law begins where the arbitrary will of him who wields the power to punish and the right of judgment has limits placed on it by the law of the state, or by custom strong as law. The law indicates objectively those immoral acts against which proceedings are to be taken on behalf of the community, and forbids similar proceedings against any other acts; the law orders the process of investigation in positive forms; the law establishes a corresponding satisfaction for each crime. The Roman public criminal law begins with the Valerian law, which submitted the death sentence of the magistrate on the Roman citizen to confirmation by the corporation, Roman private criminal law with that system which took the definite sentence of punishment out of the praetor's hands, and for the conditional sentence referred the fulfilment of the condition to the juror. From that time forth there is in Rome no crime without a criminal law, no criminal procedure without a law of procedure, no punishment without a law of punishment.

The presentation as a whole is admirable; but we must be careful not to let Nommsen's eloquence mislead us into exaggerating the effect of the first introduction of a rule of law as opposed to the rule of arbitrary command. When Mommsen says that 'hence-

refer to scourging preliminary to death (Strafrecht, p. 42, n. 1), and that stripes alone were not recognised as a substantive punishment in any regular criminal trial, but were left as a means of 'coercitio' in the hands of the magistrate until forbidden by the elder Cato (ibid. p. 47, n. 3).

is Strafrecht, p. 543. so Ibid. p. 599. si Ibid. p. 475, n. $5 . \quad$ s2 Ibid. p. 55. 
forth there is no punishment without a law of punishment,' and when in another passage ${ }^{83}$ he adds in the same strain, "The Romans were conscious that a power in the magistrate to punish, not founded on positive statute, overthrows the rule of law, and that even the permission of appeal to the people does not alter this fact,' these statements must be qualified by stretching the sense of 'positive statute' to include the highly elastic conception of perduellio, and by limiting the sense of the word 'punishment' to an extent which makes the statements almost identical propositions. These points come out more clearly later in the work. On p. 475, for instance, we find, "The entire magisterial coercitio in the proper sense of the word ... is not subject to appeal to the people;' and again, 'Appeal can be laid only against the public judgments, whose conception and sphere as opposed to that of magisterial arbitrary power, coevcitio, is defined by that very test.' Surely this is an argument in a circle, and one which further suggests a paradox. If a fresh criminal law does not create a fresh liability to punishment for the offender, but only removes another offence from the category of those which the magistrate may punish as he pleases to the category of those which he can only punish in a certain way, and under restrictions which provide every chance for escape, it seems as if that which the criminal has to fear is the absence rather than the presence in his case of this 'law of punishment without which there is no punishment.' It would have been small consolation to Matienus, for instance (above, p. 234), to be told that he was not being punished but only coerced.

Perhaps a practical solution of the paradox may be found if we consider the working of the tribunician power. Unless Matienus's case had been a very bad one indeed, so bad that no possible sympathy could be aroused for him, the tribunes would have forbidden the severe action taken against him. In delineating the respective spheres of the comitial procedure and of magisterial coercitio we must remember that the magistrate who elects to take the first method is pretty safe, so long as he confines himself to traditional practice, from the interference of the tribunician veto, whereas if the more arbitrary course is preferred it has to be taken under the scrutiny of ten pairs of watchful eyes. The tribune was always eager to pounce on any opportunity of justifying his existence and of vindicating the rights of the private man against any use of the magistrate's power which could be considered tyrannical or excessive. The practical result was that, except in a few specified cases, coercitio within the walls was limited to petty matters, and that if the magistrate wished to punish severely he would not be allowed to do so unless he put his sentence in such a form as to make it liable to appeal. It is evidence then of the

ss Ștrafrecht, p. 53, n. 1 . 
growing frequency and importance of an offence when we find that it becomes worth while for the community to interfere by passing a law against it. Though the result of this interference is in form to limit the magistrate in his power of punishing the offence in question, yet practically the law thus marks it out as deserving severe punishment, and provides a way in which the magistrate, without incurring the liability to blame or hindrance, may more effectively though more mildly deal with it. If on the other hand an offence becomes very prevalent or very dangerous, the remedy is a step backwards to magisterial power, sometimes exercised independently, if the tribunes acquiesce, as on Matienus, sometimes stirred up (as we shall see later on, p. 252) by a charge from senate or people requiring the magistrate to hold a special quaestio without appeal on the matter specified.

The invention, then, of the comitial procedure is the important point; the cases which shall be brought under it, by removal either from the sphere of coercitio or from that of private suits, are determined from time to time-' seu legibus, seu moribus ${ }^{\text {B4 }}$-custom standing on an equality with the written law.' ${ }^{85}$ Mommsen is probably right in holding that ' public jurisdiction ' first begins in the case of the Roman citizen who, by his own act, has placed himseli in the position of an enemy (perduellis). The guilt, from a Roman point of view, of the foreign enemy is notorious, and the fate which awaits him is death. In numero hostium habere is the Latin euphemism for a general massacre. But the question whether a man who was once a citizen falls under this category is one which may sometimes demand inquiry. ${ }^{86}$

The magistrate proceeds to inquire, and here we have the beginnings of a criminal trial, no matter whether he decides on his own authority or whether, as from the first he is justified in doing though not bound to do, he submits to the people the question whether to remit the death penalty on the man guilty of injuring the community or to let that penalty have its course.

The conception of the 'injury to the community' which calls for public intervention soon spreads from the deserter and the conspirator to the man who 'appropriates the goods of a temple (sacrilegium), steals the public cattle (peculatus), or injures the public buildings or roads.' Further, as early as the Twelve Tables we find certain acts, which are primarily offences against individuals, held nevertheless to be so dangerous to the public that the community directly interests itself in their punishment. This is the case with murder of a freeman (extended to cover false witness in a capital case ${ }^{87}$ ), arson, ${ }^{88}$ theft of growing corn, and the public utterance of scandalous verses against an individual. These are all ${ }^{89}$

\footnotetext{
st Livy, sxvi. 3, 8.

"Ibid. p. 155, n. 3.

*S Strafrecht, p. $151, \mathrm{n}, 1$.

ssid.p. 646, n. 2.

sc Ibid. p. 59.

soid. p. 60 .
} 
treated as public crimes, and every trace of a co-operation of the person immediately injured or of his gentiles thereby disappears; so that the subordination of the gentes to the collective body of citizens must be taken as an accomplished fact, when the law is issued. The offender under these categories is not considered as a public enemy, and his citizenship is not regarded as annihilated by the criminal act itself; but the procedure on the part of the magistrate is identical, except that in case of these crimes the inquiry is indispensable, whereas in those directly aimed at the state the notoriety of the fact may often make investigation unnecessary.

The distinction between the two categories is further kept up by the circumstance that the ordinary crime is commonly dealt with by the standing quacstores, perduellio by specially appointed duovivi, ${ }^{90}$ or later by the tribunes. But the sphere of activity of the latter is constantly increasing, and any action which they hold to be an injury to the community may be treated by them as perduellio. The trial of the censors of 169 B.c. ${ }^{91}$ for contempt of tribunician authority, and that of fraudulent contractors in the second Punic war, ${ }^{92}$ may be cited as instances. It was certainly never laid down beforehand that these particular actions should be the objects of a trial, whether for a capital or for a pecuniary penalty, but the tribunes in each case were able to make them so. 'The tribunician criminal procedure,' as Mommsen says, ${ }^{93}$ 'extended itself over the whole sphere of state trials.' The question is more difficult with crimes belonging to the parricidium class. What became of the first forger ${ }^{94}$ Was his neck wrung in the prison by the consul's coercitio? or did a quaestor condemn him for a new crime and leave him to appeal to the people? or did the injured party bring a private suit against him for damages before the praetor? These are questions which it is easier to ask than to answer.

Mommsen has done good service by clearly establishing the nature of the comitial trial, as in all cases an appeal for pardon against the sentence of a magistrate; and a good deal that is to be found in modern text-books is thereby set aside. A. W. Zumpt, for instance, ${ }^{95}$ misled by the phrase iudicium populi, which he takes

9o Strafrecht, p. 155, n. 3 , and p. 598, n. 1 . The Horatius case, undoubtedly one of 'parricidium,' has to be treated in the story as 'perduellio', because quaestors having, according to the traditional chronology, not yet been invented, the creation of 'duoviri' is necessary for the procedure.

91 See above, p..228. $\quad{ }^{92}$ Livy, xxv. 3. $\quad{ }^{93}$ Strafrecht, p. 156.

"There is a curious story in Cic. Dc Off. iii. 20, 80, referred to by Mommsen (Strafrecht, p. 672), how Marius Gratidianus as praetor entered into agreement with his colleagues and the tribunes to issue a joint edict about the coining of false money ('conscripserunt communiter edictum cum poena atque iudicio') and then took all the credit himself; but this does not help us much.

os Zumpt, Criminalrecht, vol. r. ii. pp. 141, 142. 
in a technical sense, whereas it is really ${ }^{96}$ a loose literary expression, attempts to assimilate the functions of the magistrate in such trials to those of the praetor in the proceedings in iure in civil suits, and the functions of the people to those of the unus iulex appointed under the formulary system by the praetor. $\mathrm{He}$ even ${ }^{97}$ represents the people in the trial of Horatius as exercising an authority delegated to it by the king, and believes that the king could ignore or modify the people's decision-a theory running counter to all the principles of Poman constitutional law. Much more excusable is another error which Zumpt shares with Sir Henry Maine, founded on the frequent use in literature of the words accusure and accusator, as applied to the magistrate in a criminal trial. Maine believes that the magistrate is in the position of the proposer of a law, and that it is the people which, in these cases, strikes directly at the offender by a legislative act, as we should say by a 'bill of pains and penalties.' 's This belief, however natural, proves a fruitful source of error, and leads incidentally to a total misconception on Maine's part of the nature of the quaestioncs, which he takes to be committees of the popular assemblies. ${ }^{99}$ This misconception has been logically worked out to what proves to be a rednctio ad absurdum by Professor Beesly ${ }^{100}$ in his analysis of the proceedings against Clodius for sacrilege.

In discussing the so-called iudicium populi I have nothing to do but to quote and analyse Mommsen's account and to express the fullest concurrence. The whole structure is based on the power of the magistrate.

Criminal jurisdiction-that is to say, the bringing about of the punishment of a public or private offence which infringes on the rights of the Roman commonwealth-belongs, as does judgment generally, to the rights and duties of the magistrature, and further exclusively to the officers endued with the full magisterial power, the imperium or an equivalent power. ${ }^{101}$ Whether the magistrate pronounces at his own discretion, and whether this pronouncement is final, or whether it can be cancelled by the people, or whether again the magistrate gives decisions conditional on the finding of jurors, or even makes his pronouncement in accordance with the discretion left by him to the jurors, in a legal sense every sentence is a magisterial pronouncement. ${ }^{102}$

This idea lies at the root of the whole matter, and it has important historical consequences. It is because every sentence

96 See Strafrecht, p. 116. $\quad 9$ Zumpt, Criminalrecht, vol. I. j. pp. 87, 94, 98.

98 Maine's Ancient Law, p. 381. So too Zumpt, Crim.-Prozess, p. 6, note : The jurisdiction of the tribunes and aediles, assisted by the assembly of the people, is to be regarded rather as a kind of legislative action.'

99 Maine, pp. 381-9. :00 Catiline, Clodius, and Tiberius, pp. 51-4.

10) I.e. the 'sacrosancta potestas' of the plebeian magistrates.

102 Strafrecht, p. 135. 
was held to be the work of the magistrate, and not of the people, that the liberty of the citizen came to be measured by the extent to which he was allowed to brave the magistrate by evading or alleviating the effect of sentences.

Where, then, does the part of the people come in? Here again the answer is best expressed in Mommsen's words. ${ }^{103}$

Upon the execution of the sentence the condemned man can demand the final decision of the sovereign commonalty, appeal from the magistrate to the comitia. To quash the sentence of punishment, as is craved by the condemned, is an act of sovereign power. The magistrate has answered the question of guilty or not guilty in the affirmative, and although the progress of the inquiry takes up this question again, and an acquittal by the comitia may possibly be the result of a conviction on the part of the majority of the citizens that the accused is innocent, yet the idea that forms the base of the proceedings is not that of innocence but of remission. This comes out with overwhelming force in the Horatius legend. The offence is the most serious conceivable, the perpetrator notorious and avowing the fact; but there is ground for absolution in the patriotism which atones for everything. It is quite obvious that the proceedings before the comitia must be conceived as a petition for grace. In the oldest category, that as to the forms of which we have the fullest tradition, the trial for perduellio before the droviri, it appears expressly as a cancelling of the sentence pronounced by the magistrate. It is true that in the scenes portrayed to us from later times the punishment appears not as a judgment of the magistrate who conducts the business, but as a proposal which he brings before the comitia; but the magistrate, by the very fact of defending his own sentence before the people against the petition for pardon, cannot help making a proposal to them, and so this conception does not really exclude a previous judgment on his part. The decisive consideration is that the comitia is never under any circumstances assembled to judge, but always to confirm or to overthrow a judgment, whereby any alteration or aggravation of punishment is excluded. This is nothing else than a legal expression for pardon.

Mommsen perhaps a little understates his own case. It is obvious that practically the possibility of appeal reduces the magistrate from the position of a judge to that of an accuser; he becomes a party in the subsequent proceedings, so that if the accused is finally condemned it is held to be a victory for the magistrate; si vincent, caput obnubito, \&c., says the old formula in the Horatius case. This is quite sufficient to account for the words accusare and accusator being habitually used to describe him. But not only in the capital trials for perduellio, but in those where the punishment is only a fine, the true legal conception is that of appeal from a sentence already passed. If, as Maine supposed, each trial was a direct act of legislation, it would be a privilegium of the very kind which the Twelve Tablee forbade. The true legal relations of the 
parties are thus expressed in Cicero's words : ${ }^{104}$ quum magistratus iudicassit irrogassitve, per populum multae poenae certatio esto. It may be true, as Mommsen thinks, ${ }^{105}$ that the word irrogare etymologically contains a reference forward to what the magistrate will have to do when the matter comes before the people (that is, to ask them to consent to his sentence), and it is certainly true that the appeal in later times is always taken for granted from the beginning of the proceedings, so that the magistrate seems to invite the cooperation of the people, without waiting for their intervention to be claimed ; but nevertheless irrogare in this passage of Cicero is used in strict parallelism to iudicare, and the proceedings that are to follow are the same in both cases, and so irrogare must, in law if not in etymology, mean at the moment of pronouncement 'to impose' a fine, not 'to propose' one. ${ }^{106}$ About iudicare ${ }^{107}$ there is no question that it means to 'condemn,' and strictly to 'condemn to death;' and the use of the phrase in this sense is not confined to primitive times or to the duoviral trial. The perduellionem tibi iudico of the duovir to Horatius is expressly repeated by the tribune. of 211 в.c., perduellionis se iudicare Cn. Fulvio, and by the tribune of 169 в.о., utrique censori perduellionem se iudicare pronuntiavit, ${ }^{108}$ and Caesar in 63 в.o. doubtless used the same words to Rabirius, when--sorte iudex in reum ductus tam cupide condemnarit, ut ad populum provocanti nihil aeque ac iudicis acerbitas profuerit. ${ }^{109}$

The moral and political aspect of provocatio is summed up in a passage ${ }^{110}$ of singular force and eloquence.

This mighty act of fettering the imperium still bears upon it the marks of its original germ. That power by virtue of which the magistrate in the comitial criminal trial pronounces the first sentence is the same by virtue of which he judges without restraint women and strangers. In so far as that power is bound to justify its sentence before the community and ceases to bave the last word its arbitrary character is limited but not removed. Furthermore the arbitrariness of the final decision is not altered but only transferred. This form of trial is not subject to the law in the same way as that power of punishment which has its organ in the jury trial. . . . It is a magnificent act of political self-restraint that the omnipotence of the assembly is brought to a stand if the magistrate acquits, that no citizen can be condemned to

104 De Leg. iii. 3, 6 .

los Strafrecht, p. 166, n. 3.

${ }_{108}$ In the early inscriptions respecting sacred enclosures quoted by Mommsen (Strafrecht, p. 158, n. 3) 'multare' and 'multam irrogare' seem to be used indifferently in the several versions of the same formula. The jurists of the principate, to say nothing of laymen, constantly use 'poenam irrogare' in the sense of 'to inflict.'

${ }^{107}$ See Strafrecht, p. 3, n. 2, and p. 769, n. 4. Zumpt, who thinks that there was an appeal in case of the duoviri, but in case of all other magistrates a sentence in first and last instance by the people, has to draw just the opposite conclusion from the parallelism of ' iudicare ' with 'multam irrogare,' and to explain away the sense of ' iudicare 'in all cases except that of the duoviri (Criminalrecht, r.ii. 185-92). I need hardly say that I think him wrong.

108 Livy, xxri. 3, 9, and zliii. 16, 11. ${ }^{109}$ Suet. Jul. 12. 110 Strafrecht, p. 171. 
heavy public punishment except by the agreement of the magistrate and the community; but pardon is no less arbitrary; and unrighteous acquittal is no less a wrong. The Roman criminal law is certainly the most powerful manifestation of ciric freedom and the most majestic tribute to that freedom ; but it has the defects of its qualities, the coarse egotism which asks no questions about women and foreigners, the weak clemency towards offending citizens, the arbitrary power which is shackled, but not abolished.

The introduction of compulsory provocatio is universally attributed to the lex Valeria of the first year of the republic, and is thus brought into the closest connexion with the abolition of kingship.

This may be a legend (says Mommsen), but even so there is all the more reflected therein the necessary connexion of the democratical principle with the exclusive right of the community over the life and death of a citizen. ${ }^{111}$

The earlier laws on provocatio are said to have had for their sanction only the phrase improbe factum videri. Mommsen explains this to mean that

if a magistrate ignores the appeal, and carries out the death sentence in spite of it, his office will no longer cover his action, and the action will be regarded as that of a private man, and so punished as murder. ${ }^{113}$

This very plausible interpretation can hardly have been known to Livy, who evidently regarded ${ }^{113}$ the mere expression of moral censure as having been a vinculuin satis validum legis in that golden age. Mommsen's explanation seems undoubtedly right.

With provocatio comes a change in the insignia of the city magistrate, by the removal of the executioner's axe from the fasces of his lictors.

This (writes Mommsen) is the symbol not of the abolition of the punishment of death for citizens, which only changed its form, but the exclusion from the city ring-wall of the rules of war, by virtue of which the wielder of the imperium could down to this time order the head of the disobedient citizen, as of the disobedient soldier, to be laid at his feet (p. 917).

It is a curious paradox that the forms of punishment still publicly inflicted on eitizens were all more cruel than beheading. According to the Twelve Tables the incendiary is to be burned alive; if Mommsen's interpretation ${ }^{114}$ be right, the death in the sack was anciently inflicted on all murderers, the reservation of it as a special penalty for slayers of their owu kindred being an innovation; and crucifixion is really meant by the punishment

$$
\text { "'1 Strafrecht, p. } 162 . \quad{ }^{112} \text { Ibid. p. 167. } 1 \text { "s Livy, x. 9, 6. }
$$

iis Strafrecht, pp. 643, 918-922. Mommsen points out that 'parri-cidium' has nothing to do with 'patricidium,' but that the prefix has the same meaning of 'bad' ss the 'per-' in ' per-duellio' and 'per-iurus.' 
prepared for Horatius, ${ }^{113}$ the suspensum Cereri necari for the harvest thief in the Twelve Tables, and the punishment more maiorum threatened for Nero on his deposition. I think that Mommsen has gone far to establish these points, though he admits that they were commonly slurred over by the writers of the classical period, who regarded with horror the infliction on citizens of what was later a servile punishment. In practice these public executions were doubtless confined to very heinous cases, ${ }^{116}$ and private executions by strangling in the prison supplemented them at the discretion of the magistrate for ordinary malefactors. It may well be that the magistrate soon found it necessary to pledge himself beforehand not to inflict the more cruel punishment, lest he should give the accused the opportunity of miserabiliores epilogos, ${ }^{117}$ which might induce the people to acquit him altogether.

It somewhat upsets our preconceived notions to find that death by smiting off the head, which we are accustomed to regard, and which was regarded under the principate, as a comparatively dignified form of public execution, was under the early republic reserved in the city for strangers, enemies, and deserters. This can only be explained by the close connexion of that form of punishment with the arbitrary proceedings of military justice; and I am strongly inclined to think that this connexion, which Mommsen justly emphasises, dates from the earliest times, and that there is no occasion for his other somewhat fanciful explanation ${ }^{118}$ of beheading by the axe as 'answering to the ritual of sacrifice, and originally, doubtless, conceived as the offering up of a human victim.' Only two passages are quoted by Mommsen in support of this contention. The first ${ }^{119}$ is a strange story in Dio Cassius (xliii. 24) of how in the year 46 B.c., under Caesar's dictatorship,

two men were slain as victims with a kind of ritual; and the reason for this I cannot tell, for it was not prescribed by the Sibyl or any other oracle; anyhow they were sacrificed in the Campus Martius by the pontiffs and the priest of Mars, and their heads were set on the Regia.

I can offer no explanation of this, but Mommsen's solution - that this is without doubt a recurrence to an antique form of execution ' does not seem very convincing. ${ }^{120}$ In the other instance

113 This comes out clearly in Cic. Pro Rab. perd. 4, 11, and 5, 16. For Nero's case see Suet. Ner. 49.

11. This may explain why Cicero and the jury to which be spoke in the case of Roscius of Ameria evidently believed that the sack had never been used except for murderers of near kinsfolk, and why crucifixion came to be practically confined to slaves and subjects.

"17 See Cic. Pro Planc. 34, 83. Dio (xxzii. 39) notices that in bribery cases the lighter the penalty the easier it was to get convictions.

i's Strafrecht, p. 902.

119 Ibid. p. 913.

1:0 I do not even feel sure that Dio means us to understand that these two persons 
Mommsen's theory certainly seems to have led him into an erroneous interpretation of his Latin authority. In the words of Festus-

Homo sacer est quem populus iudicavit ob maleficium, neque fas est eum immolari, sed qui occidit parricidii non damnatur-

he sees ${ }^{121}$ an

antithesis between the magisterial execution by way of immolatio, carried out according to fas, and the private and plebeian execution carried out by way of self-help without magisterial action.

That sacratio leads to this popular execution is undoubted, but the proper magisterial immolatio, supposed to be the antithesis to this, is read into the passage and not found there. By neque fas est Festus obviously meant nothing of the sort, but merely wished to negative the shocking supposition which might seem to be conveyed by the word sacer, that a buman sacrifice was actually contemplated. ${ }^{122}$ Festus does not say that the criminal is called sacer because it is under certain accidental circumstances (the absence of a patrician magistrate) improper to sacrifice him, but notices (as is perfectly natural) that he is called sacer although it is always nefas to think of such a thing as human sacrifice. The Latin and the sense alike require us to take the words neque fas est, \&c., not as part of the relative sentence but as continuing the principal sentence, and to translate - ' not that it is lawful to sacrifice him, but \&c.'

Another consequence of provocatio is that the superior magistrate withdraws from administering ordinary criminal justice. When King Tullus Hostilius resolves that an appeal shall be granted to Horatius he omits himself to judge and condemn, but appoints special officers for the purpose. So under the republic ${ }^{123}$ the chief magistrate thinks it beneath his dignity to utter a sentence which may possibly be reversed, and designates for this function less eminent persons, quaestors or duumvirs, who ' cannot plead their estimation; ' and the same task is undertaken by the tribunes, who, for all their power, are modest folk when compared with the splendour of the curule magistrate. Of the quaestors I need only say that Mommsen holds ${ }^{124}$-and he is probably right-that the quaestores parricidii are not a separate board, but are identical with the urban quaestors of historical times. For the duoviri, he believes ${ }^{125}$ that a special law was required to bring them into existence on each

were (like the one mentioned by him in the previous sentence) mutinous soldiers, as Mommsen assumes (Strafrecht, p. 913, n. 6).

121 Ibid. p. 902, n. 1.

122 Dionysius (ii. 10) gives substantially the same definition of 'sacer,' $2 \nu \forall \theta \in t$ ydp

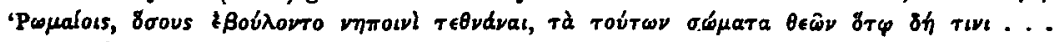

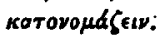

121 Strafrecht, p. $154 . \quad{ }^{124}$ Tbid. p. $155 . \quad{ }^{123}$ Ibid. p. 527. 
occasion (a supposition difficult to reconcile with Cicero's expression hic popularis a duumviris iniussu vestro ${ }^{125}$ ), and further ${ }^{127}$ that, after the expulsicn of the kings, they were elected by the people. Mommsen does not quote any authority for the last statement, and I know of none save that of Dio Cassius, who says (xxxvii. 27,2) that the duoviri in Rabirius's case were appointed by the praetor

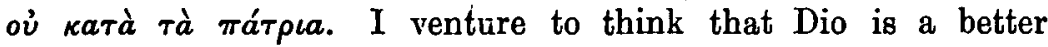
authority for what certainly took place on this occasion than for an antiquarian objection to the practice recorded. It is very im. probable that Caesar and Labienus, when furbishing up the rusty machinery of antiquated procedure in this case, should have introduced an innovation, especially one so contrary to democratic principles. Dio's statement may very likely be a mere inference ${ }^{128}$ on his part from the rhetorical blame conveyed by Cicero in the words quoted above (iniussu vestro).

Several interesting points are dealt with in Mommsen's lucid account of the procedure in comitial trials. The first step is for the magistrate to summon the suspected person to appear before him on a specified day (diei dictio). On that day begins ${ }^{129}$ the anquisitio-etymologically a strengthened form of quaestio. This is conducted publicly, the citizens being summoned to a concio to listen, 'evidently with regard to the final decision by them, which is anticipated.' The magistrate must not conclude this hearing in a single day, but is bound to adjourn it twice (diem prodicere). At these sittings any citizen may with the permission of the magistrate make himself heard, and the magistrate cannot decently refuse leave, though he may limit the speeches : thus in Rabirius's trial in 63 B.c. Hortensius and Cicero were permitted to play the part of advocates, but were allowed only half an hour apiece to speak in, and that probably on different days (antea, Pro Rab. 6, 18). At the third sitting the magistrate pronounces, and it is not till then that he is bound finally to decide what his sentence is to be. ${ }^{130}$ If he acquits there is an end of the matter; if he pronounces for death (iudicium) the appeal will be to the comitia centuriata, if for a fine (multae irrogatio) to one of the two tribal assemblies (populus for quaestors, plehs for tribunes). It is the difference of the assemblies (8o Mommsen thinks ${ }^{131}$ ) which determines the rule that a

128 Pro Rab. perd. 4, 12.

127 Strafrecht, pp. 154, 587.

128 Strange to say, Zumpt (Criminalrecht, r. i. p. 93) does actually argue from the words of Cicero in the very way in which I conjecture that Dio may have argued : 'Auch Cicero wirft diesen Zweimännern ihre Ernennung durch den Praetor vor, und doch wäre dasselbe gesetzlich gewesen, wenn in Horatius' Processe der König sie selbst erwählt hätte.' 129 Strafrecht, p. 164.

120 Mommsen (p. 165) quotes several instances. The best are the trials of Cn. Fulvius (Livy, xxvi. 3), when the tribune 'cum bis pecunia anquisisset, tertio capitis se anquirere diceret,' and of Menenius (Livy, ii. 52, 5) 'quum capitis anquisissent, duo millia aeris damnato multam dixerunt.'

181 Strafrecht, p. 167, n. 1. 
capital and a pecuniary penulty cannot be conjoined. ${ }^{132}$ In either case the usual twenty-four days' notice must be given for this 'fourth accusation,' 133 at which the citizens appear for the first time, not as mere listeners, but in their sovereign capacity to decide the issue. Cicero's summing up of the regular procedure ${ }^{134}$ now comes out quite clearly: ne improdicta die quis accusetur, ut ter ante magistratus accuset intermissa die quam multam irroget aut iudicet, quarta sit accusatio trinum nundinum prodicta die, qua die iudicium sit futurum.

Another point is brought out by Cicero in the same passagenamely, that if on account of the auspices or for any other reason the comitia separates without coming to a decision, the meeting cannot be adjourned to another day, and so tota causa iudiciumque sublatum est. C. Claudius Pulcher, who lost the battle of Drepana in 259 B.c., escaped by a sudden rainstorm at his trial: the tribunes would not allow the capital trial to be renewed, but Claudius was heavily fined. ${ }^{135}$ Mommsen is certainly right in his remark ${ }^{136}$ - This can have been nothing but custom supported by tribunician intercession; for example, no notice is taken of it in the trial of M. Manlius.' ${ }^{137}$

One of the most interesting of our authorities for this procedure before the comitia is the 'Commentarium vetus anquisitionis $\mathrm{M}$ ' Sergii M' f. quaestoris qui capitis accusavit Rocum,' fragments of which are preserved in Varro's book 'De Lingua Latina.' Amongst the instructions we find patres censeant exquiras et adesse iubeas. Mommsen's interpretation is ${ }^{138}$ that

this must be referred to the custom of getting together counsellors before taking weighty decisions, since it was open to the magistrate to let the case drop after the appeal had been entered. The magistrate then in this case has to betake himself to the senate as the consilium publicum. The consulting party was doubtless not legally bound by the advice thus given him.

This interpretation is possibly right, and it would supply a precedent by way of analogy for Cicero's consultation of the senate about the Catilinarian conspirators. It is strange, however, that we hear of no such consultation in any of the historical cases of a trial before the comitia; one would have thought that such an expression of opinion would have had great weight as a prae-iudicium, and that its effect in each case would certainly have been noticed in the

\footnotetext{
192 Though Cicero lays some stress on this last point in his arraignment of Clodius's procedure, it loses much of its practical importance when we remember that the goods of the man convicted of 'perduellio' fell as those of a natural enemy to the state (Strafrecht, pp. 72, 1006 seq.)

123 Ibid. p. $169 . \quad$ ist De Domo, 17, 45.

133 Zumpt, Criminalrecht, r. ii. p. 311.

15. Livg, ri. 20, 11.
} 
story. It is a further difficulty that the ius senatus habendi is never known to have been delegated, and certainly did not belong to the quaestor in his own right. The senate was not 'of counsel' to him but only to the superior magistrates. Perhaps the instruction merely means that the quaestor was politely to express his anxiety for the presence of the leading men of the state at the trial, and his hopes for the benefit of their advice during the debate. In any case I cannot think that Mommsen is right in explaining by reference to such consultation the difficult passage of Polybius (vi. 16) with which I shall deal later (below, p. 258).

Another interesting question arises in connexion with the case of Rocus.

In such a summons (says Mommsen) there arises the complication that the comitia centuriata could be called together only by one vested with the imperizm, and that the three magistrates qualified to initiate such proceedings, the duoviri perduellionis, the quaestors, and the tribunes of the plebs, did not possess the necessary imperium. ${ }^{139}$

M' Sergius is therefore instructed 'to send and ask for auspices from the consul or the praetor.' In the same way, when the tribune applies to the praetor urbanus for ' a day of the comitia centuriata' it is probably to be understood that the praetor lends him auspices to enable him to summon the assembly. In the case of the quaestor it is pretty clear from the account in Varro that he, though devoid of imperium, will himself preside in the romitia when assembled by virtue of his auspices, which he takes in this delegated capacity from his superior; and the same is probably true of the tribune. It is not altogether easy to gather from Mommsen s statement (p. 168) whether he adopts this view, but on the whole I think this is his meaning. By parity of reasoning we should suppose that not the king but the duoviri presided at the trial of Horatius. Livy in his story does not definitely commit himself as to the presidency, but, as the king is not mentioned after the cluoviri are appointed, the silence of the narrator points the same way.

The same question, as to who presides, arises in the trial of Rabirius in 63 в.c., and it is further complicated by a doubt as to whether Rabirius was tried once or twice. Mommsen believes ${ }^{140}$ that after his escape on the charge of perduellio Rabirius was fined by the tribune, and that it was on his appeal against the multae irrogatio that Cicero delivered the speech in his favour which is still extant. I am inclined to think that the multae irrogatio mentioned in the speech refers to some earlier proceeding, and that the perduellionis iudicium a me sublatum does not imply that

120 Strafrecht, p. 168.

${ }^{1+0}$ This seems at least to be stated on p. 582. I do not see how this is to be reconciled with p. $888, n$. 1 , where he says 'Rabirius could not be put on his trial twice over.' 
the accusation for perduellio was passed and done with, but only that Cicero had prevented Labienus from carrying through the trial according to the traditional forms of the Horatius case, with arrest of the prisoner beforehand and the actual infliction of death in case he were found guilty. That the accused, at the moment when the speech was delivered, was not in danger of actual execution is quite clear from the whole tenor of Cicero's language, and this much is admitted on all hands. If Mommsen's view be correct the second trial would undoubtedly be before the plebs, with the tribune presiding. On the other hand, if the occasion be the trial for perduellio, a puzzling question is left as to the presidency. It is certainly strange that in Cicero's speech ${ }^{141}$ only the tribune is mentioned as controlling the proceedings. Perhaps the speech was delivered at one of the preliminary meetings in concione (described above on p. 246), at which the tribune might well claim to restrict the length of the speechee. Anyhow it is not clear who presided on the final day. Analogy would lead us to expect the duoviri; yet it is Metellus, the praetor, who appears in Dio's account as the controller, and who breaks up the comitia centuriata by striking the flag. ${ }^{142}$

The consideration of the trial of Rabirius leads us to the most important historical result brought about by the machinery of appeal-the practical abolition of the punishment of death. We read in the early story how Kaeso Quinctius and Coriolanus and eight of the decemvirs were allowed to escape death by going into exile. The practice rapidly gained ground, so that by the time of Polybius it was the settled custom that in a capital trial the accused was free, until the last vote had been cast, to 'depart openly, sentencing himself to voluntary exile; and the banished man will be safe if he retires to Tibur, Praeneste, or Neapolis, or any other state with which Rome has a sworn treaty.' ${ }^{143}$

It is obvious that such a departure could take place only when the criminal was at the moment in physical liberty, whether or not bail had been given for his appearance; ${ }^{144}$ and in the case of Kaeso Quinctius we find that his previous arrest is urged ${ }^{145}$ on the

141 Zumpt (Criminalrecht, I. ii.p. 396) ingeniously suggests that the speech, as delivered, may have contained many references to Caesar and his brother duumvir which were omitted on its publication in 60 B.c. It is certainly noticeable that the same letter (Ad Att. ii. 1) which announces the publication of his Consular Orations records Cicero's hopes of being able to influence Caesar in a friendly way and bring him round to a sound policy.

142 Mommsen (see above, p. 245), and others believe (though Dio does not seem to me to say so much) that a special law was required on each occasion before 'duoviri perduellionis' could be created. If so, the question who was to preside at the assembly might, of course, be settled differently in each case by a clause of the special law. $\quad 143$ Polyb. vi. 14,7. 14t Strafrecht, pp. 70, 71.

its Livy, iii. 13, 5. "Ut qui hominem necaverit de eo supplicii sumendi copia populo Romano fiat.' 
ground that only so will the people have the opportunity of exacting the penalty from him. On one occasion, that of the accomplices of the fraudulent contractor Postumius in the second Punic war, the circumstance that the tribunes are disposed to arrest the accused beforehand leads many to go straight away into exile without standing their trial; ${ }^{146}$ probably here likewise something worse than exile might have happened to them if they had been found guilty while under arrest; Polybius too seems to imply that death is in store for the accused who has waited too long and against whom the decision of the assembly has been actually given.

So far as I know there are only two cases in the story of the Roman republic in which the law is distinctly said to have run its full course-that is to say, in which the criminal was allowed to appeal, the comitia decided against him, and the punishment of death was publicly inflicted. The two cases are those of Sp. Cassius and M. Manlius, both executed for treason. The two most guilty decemvirs, Appius Claudius and Sp. Oppius, were doubtless saved by suicide from a like fate.

Pleminius, the lieutenant of Scipio Africanus, who had been guilty of the grossest outrages on the inhabitants of the Italian Locri, was seized as he was retiring to Naples for exile, and thrown into the prison of Rome, which he certainly never left alive. Contradictory accounts ${ }^{147}$ are given of his end, and it is impossible to rnake out whether he was really tried or executed. Suicide in prison is recorded ${ }^{148}$ of a certain C. Cornelius, accused of rape; he probably anticipated by his death a trial before the centuries. ${ }^{149}$ The condemnation is mentioned ${ }^{150}$ of three parricides, Hostius (circ. 200 B.c.), Q. Fabius (circ. 100 B.C.) and Malleolus, of the same date. Of the last named it is expressly said ${ }^{151}$ that he perished in the sack, and Mommsen ${ }^{152}$ is probably right in arguing from his fate that, though at that time ordinary murder was already the subject of a jury trial, which did not admit of

140 Livy, xxv. 4, 11.

147 Ibid. xxix. 22, 9; xxxiv. 44, 6. 1ts Val. Max. vi. 1, 10.

14 Mommsen (Strafrecht, p. 961, n. 6; Staatsrecht, iii. p. 1069, n. 3, and p. 1250, n. 1) takes a different view. He considers both Pleminius and Cornelius to be men already condemned to death (apparently by the centuries), whose execution was put oti indefinitely by the magistrates, so as to make their sentence practically one of imprisonment for life. He considers that this was likewise the meaning of Caesar's 'sententia' on the Catilinarians. I find it difficult to believe that Caesar so completely justified the legality of Cicero's act as to join in the sentence of death, or that the only difference in point of law between Cato and Caesar was that the one wished the death sentence to be carried out at once, and that the other wished the same sentence to be indefinitely suspended. It seems strange for me to be arguing for Caesar against his great adrocate and the great disparager of Cicero; still, as a matter of history, I think that the explanation which I have offered elsewhere (Life of Cicero, p. 142) is the more probable. At any rate it exhibits Caesar's action as more logical and consistent.

ist Ad Her. i. 13, 23.

iso See Strafrecht, p. 614, n. 1.

1s: Strafrecht, pp. 174, 644 . 
previous arrest, or consequently of actual execution, cases of parricide must have been reserved for the comitia almost ${ }^{153}$ down to the legislation of Sulla. These three cases may, I think, fairly be added to those of Cassius and Manlius, as instances of public execution following a vote of the people.

In all the other cases of a trial before the centuries which are recorded in our annals the person found guilty escapes death by exile. The explanation is doubtless to be found in the activity of the tribunes, which caused the seizure of the person, the condition precedent for actual execution, to fall into desuetude. ${ }^{154}$ It was in the power of any one of the tribunes to interpose his auxilium and let the accused man out of prison; and the constant presence of this power of release seems to have led to the habit of not attempting to arrest. In the 'Commentarium vetus anquisitionis' 155 there is not a word about any such proceeding in a capital trial. The house of the accused is still his castle; the instructions are that M' Sergius is to send the trumpeter to 'blow his horn before the door of this wicked T. Quinctius Rocus, the same being a private person, and bid him to appear on the Campus Martius at daybreak.' No obstacle, therefore, is opposed to the retirement from Rome. On the other hand we find that there were certain persons capitalem fraudem ausi $i^{1: 6}$ in prison at the time of the battle of Cannae, who were released on condition of enlisting in the army in that moment of supreme danger. It is possible, as Mommsen suggests, ${ }^{157}$ that the tribunician auxilium, though freely granted to state offenders or men of rank, would often be refused to the common criminal, and that for such persons previous arrest, with the possibility of death being actually inflicted, was not uncommon in the middle period of the republic. By the time of Polybius it must have almost disappeared, for he speaks of the custom of allowing exile as universal. The clumsiness of the comitial machinery may have contributed to this; it no doubt saved a great deal of trouble if accused persons, as in the case of Postumius's associates, were content to save their skins in exile; but still more effective was the growing feeling that every such evasion was an assertion of the rights of the private burgess against the magistrate, whose power of punishment was thus curtailed, and the difference, thus proclaimed, between the Roman, though a criminal, and the outlander flattered the pride of citizenship. It seems a strange privilege that every Roman, just once in

133 Not quite; for Mommsen points out (p. 644, n. 1) that a reference to the ' iudices' in a case described by Cicero (Pro Rosc. Amer. 23, 64) in в.c. 80 as 'non ita multis ante annis ' shows that the reservation cannot have lasted quite down to Sulla.

154 Bee Strafrecht, p. 327.

iss Varro, De L. L. vi. 92.

iss Livy, xxiii. 14, 3. Mommsen thinks that these would include both prisoners awaiting trial and condemned persons in whose case execution had been suspended.

137 Strafrecht, p. 328. 
his life, should be allowed to commit a crime deserving death, without death being inflicted; but a privilege it was esteemed. I believe (though the point is open to dispute) that the privilege was extended even to the common criminal, ${ }^{158}$ the housebreaker or assassin caught red-handed, if only he were a Roman citizen; once he has renounced his citizenship by exile, he must be careful not to offend again, or he will be treated as a mere foreigner; the habitual criminal is not tolerated.

We now come to far more difficult problems, to which I have already referred in passing (above, p. 238). They relate to cases in which the magistrate is specially commissioned to try cases without appeal. At the risk of tediousness it will be necessary to mention these cases individually. The earliest of them is ascribed in the annals to the year 413 B.c. M. Postumius, a military tribune with consular power, had been murdered by his soldiers, and the consuls of the next year were empowered by decree of the plebs to hold a criminal court (quaerere) on the matter. Some guilty persons perished, whether by suicide or execution Livy is uncertain. ${ }^{159}$ Mommsen (p. 172, n. 1) rejects this story as an invention of later times; it is difficult to follow his reasons, but the matter need not be pressed. There are at least three cases ${ }^{160}$ (in B.c. 331, 180 , and 152) when an epidemic of poisoning appears among Roman matrons, and each is dealt with by a special quaestio. The quaestio of 180 B.C ${ }^{161}$ is said to be ex senatus consulto. Many women seem to have been put to death; ${ }^{162}$ but in their case Mommsen does not allow that the difficulty as to provocatio ${ }^{163}$ arises. The next case, that of a Capuan conspiracy in 314 B.c. which had ramifications in Rome, may likewise be passed over; for on this occasion a dictator, C. Maenius, was appointed, and if Mommsen be correct in the date which he conjecturally assigns ${ }^{164}$ to the limitation placed on the dictator's powers in later times ${ }^{165}$ a dictator in 314 B.c.

1so See below, p. 272 .

159 Livy, iv. 51, 3: 'Per paucorum supplicium, quos sibimet ipsos conscisse mortem satis creditum est, transacta re.' The Romans would have been the better for a provision similar to that which ordains a coroner's inquest on the body of every criminal executed in prison in England.

160 Strafrecht, p. 143.

sot Livy, xl. 37,4. 192 Val. Max. (ii. 5, 3) says 170 on one occasion.

163 I have not attempted to traverse in this article the doctrine, proponnded with much confidence by Mommsen, that women lacked the right of 'provocatio.' As a matter of fact it seems to me very doubtful. It makes it difficult to explain the trial of Claudia (Suet. Tib. 2 ; see discussion in Strafrecht, p. 53, n. 1), that of Manilia (Aulus Gellius, iv. 14), and the cases mentioned in Livy, xxv. 2, 9, where the women go into exile just like men. Of course women were not members (Gell. v. 19, 10) of the comitia, but no more were the Campanian 'cives sine suffragio;' yet in 210 B.c. the senate (Livy, xxvi. 33) had to get special leave of the people before dealing with them. In the Lex Acilia, verse 78, the successful accuser who refuses the citizenship nevertheless gets 'provocatio,' so that the right to vote cannot have been a condition precedent of the right to appeal.
so Staatsrecht, $\mathrm{ii}^{3} .165$.
ias See Festus, s.v. 'optima lex.' 
was still free from prorocatio. After an interval of more than a century we find the famous case of the Bacchanalian conspiracy of the year 186 B.c., which was dealt with in this and the following year. This must be treated more at length hereafter. Meanwhile we pass to the year 172 B.c., the first occasion on which Mommsen ${ }^{156}$ allows the existence of a special criminal court. This was held by the urban praetor, C. Licinius, acting on a decree of the plebs (Lex Marcia), to compensate and punish the wrongs which some Ligurian tribes had suffered at the hands of the late consul, Popillius. The proceedings were rendered ineffectual by the collusive action of Licinius. ${ }^{167}$ A somewhat similar case in B.c. 150 against Ser. Galba for his treatment of the Lusitanians collapsed at an earlier stage. A legislative proposal (analogous to the Lex. Marcia) was brought before the people, and supported by Cato, but thrown out by Galba's influence. . $^{168}$ More effective was a commission in the year 141 B.c. ${ }^{169}$ against L. Hostilius Tubulus, who as praetor ${ }^{170}$ had been bribed to effect the condemnation of innocent persons. The consul Servilius Caepio was commissioned under a plebiscitum proposed by P. Mucius Scaevola to proceed against him, and Tubulus retired into exile without awaiting his trial. ${ }^{171}$ According to Asconius he was afterwards arrested (probably, as Mommsen supposes, ${ }^{172}$ for some fresh crime) and committed suicide ne in carcere necaretur. In the year 138 B.c. we find the consuls holding a quarstio under decree of the senate on the members of a certain company of Roman publicans, who were accused of organising brigandage in South Italy. After a protracted trial they were acquitted. ${ }^{173}$ Finally we have the proceedings against the adherents of Tib. Gracchus, carried out by P. Popillius Laenas, the consul of 132 B.c.

In all these cases there are certain common features which

\footnotetext{
106 Strafrecht, p. 172, n. 2.

${ }^{10 r}$ Livy, xlii. 22.
}

188 I adopt Mommsen's interpretation (Strafrecht, p. 172, n. 2) with slight variation; but, as we have no longer Livy to guide us, the detuils are very doubtful. This may have been an ordinary trial on appeal before the 'comitia.'

169 Mommsen has the date and name right on p. 197, but on p. 173, by misprint or slip of the pen, he gives 132 B.c. as the date, and calls the law 'Sempronia' instead of 'Mucia.'

170 Tubulus is said by Cicero (De Fin. ii. 16, 54) to have exercised a 'quaestionem inter sicarios.' It is doubtful whether he too was acting in the previous year as special commissioner (so Zumpt, Crim. Recht, ir. ii. 141), or whether, as Mommsen thinks (Strafrecht, p. 615), his case is evidence of a standing jury court for murder half a century before Sulla. I am inclined to think that the story of $L$. Cassius (consul in 127 B.c.), which is the origin of the proverbial ' Cui bono? ' points to a relation between the 'quaesitor' and his assistants in murder trials of this period more proper to a commissioner with his 'consilium' of advisers, chosen by himself, than to the standing jury-courts, in which the president never commented on the evidence: ' quotiens quaesitór iudicii alicuius esset in quo quaerebatur de homine occiso, suadebat atque etiam praeibat iudicibus . . . ut, quaereretur, cui bono fuisset perire eum, de cuius morte quaerebatur' (Asconius, in Milon. p. 46).

111 Cic. De Fin. ii. 16, 54.

12 Strafrecht, p. 71, n. 1, and p. 197, n. 2. See Asconius in Scaur. p. 23.

" Cic. Brutus, 22, 85. 
distinguish them from the regular criminal trials, of which that of T. Quinctius Rocus is a typical instance. In the first place the superior magistrates, the consuls and praetors, play an active part ; secondly, there is no mention of appeal to the people after the magistrate has condemned; thirdly, the accused are not always allowed to go into exile, but are thrown into prison, suicide being the usual result; fourthly, in two cases, that of the Bacchanalian conspirators and that of the adherents of Tib. Gracchus, wholesale executions take place. There is, further, a distinction to be noticed that in the two last named cases, and in that of the publicani in 138 в.c., there is no previous decree of the people, whereas in the others we hear of a special law regularly passed.

Mommsen's opinion on the legal character of these trials has undergone a startling alteration since the publication of the first edition of the 'Staatsrecht,' and it is questionable indeed whether in this case second thoughts can be allowed to be best. He now ${ }^{174}$ treats as of one class-to which, by the way, he denies the current appellation of quaestio extraordinaria, preferring the term mivilegium-all the cases in which a decree of the people has ordained any sort of special trial, whether by a magistrate or quaesitor deciding on his own responsibility, or by a jury court of which the magistrate is merely the president. This category is made to include (by no means to the furthering of clearness of classification) a long list of later cases-the Peducaean ${ }^{175}$ plebiscite against the defaulting vestals in 114 B.c., the Mamilian of 110 в.c. against the accomplices of Jugurtha; the action taken in 103 B.c. against Caepio after his defeat by the Cimbri for plundering the temple of Tolosa; ${ }^{176}$ the Varian law of 91 s.c. against the associates of Drusus, the Fufian of 61 B.c. against the sacrilege of Clodius, the Pompeian of 52 B.c. under which Milo was tried for killing Clodius, and the Pedian of 43 B.c. against the assassins of Caesar.

All these decrees of the people (says Mommsen ${ }^{17 i}$ ) are unconstitu. tional ; nevertheless the omnipotence of the law overrides the prescriptions of the constitution, and accordingly they are blamed, but their legal validity is not disputed.

The word ' unconstitutional,' as applied by Mommsen in this passage, may perhaps be explained by a sentence in the third

174 Strafrecht, p. 196 scq. $\quad$ "s See sbove, p. 222.

11 So Mommsen (Strafrecht, p. 198). Zumpt seems to believe (Crim.-Proc. p. 476) that there was more than one prosecution, and be places one trial in 95 B.c. The nature of the proceedings is in any case very obscure. If Valerius Maximus (iv. 7, 3) is to be trusted, Caepio was actually thrown into prison, but released by a friendly tribune, L. Reginus, who accompanied him into exile. In another passage (vi. 9, 13) Valerius says that he was strangled in prison. This may possibly be true of his second trial, if there were two, but at one time he escaped by exile, for Cicero (Pro Balbo, 11, 28) sags that he became a citizen of Smgrna.

"I Strafrecht, p. 199. 
edition of the 'Staatsrecht' (II. i. 110). After the cessation of the dictatorship, he says,

such a cognitio could be called into life only by a decree of the people, and further the comitia were not, strictly speaking, qualified to erect such a tribunal, since the institution of a magistracy without appeal was forbidden in a general law.

The objection seems somewhat forced ; for it is obviously one thing to set up a magistrate, such as Sulla or Caesar, whose decisions generally are to be free from the possibility of appeal, and another for the people in the plenitude of its power to set aside appeal in a particular case, and to order a magistrate to deal with that case.

A somewhat different classification of the cases enumerated will be suggested later on ; but in the meanwhile the great case of the Bacchanalian conspirators remains unexplained. It is perfectly clear from Livy's very circumstantial account that no special law was proposed to the people. The magistrates act on the strength of a senatus consultum, which is merely read out to the people in a concio. Nevertheless multitudes are put to deathadducti ad consules fassique de se nullam moram iudicio fecerunt-and plures necati quam in vincula coniecti sunt. ${ }^{178}$ Mommsen now believes that what the consuls are here described as carrying through was only a preliminary inquiry. ${ }^{179}$

To the 'question' of the consul every one must needs answer, in case a tribune does not come to his assistance; any distinetion according to the condition or sex of the accused is quite inconceivable on the occasion of the inquiry. But when once this has come to an end, and the magistrate is convinced that a capital crime has been committed, the guilty persons are not all treated in the same way; the consul himself condemns to death the women, foreigners, and slaves, and executes the sentence; against the citizens the formal process which we shall describe just now (i.e. the trial before the conitia) is instituted.

Mommsen had already hinted at this extraordinary solution in the third edition of the 'Staatsrecht' (ii. p. 112).

The decree of the senate eeis rem caputalem faciendam, so the original document runs, does not, it is true, exclude provocatio in cases where the same is otherwise applicable; still it appears astonishing in the highest degree that in no one of these cases is there so much as a hint that provocatio took place.

The objection, which seemed sufficiently staggering in 1887, has lost its force for Mommsen in 1899. He now says ${ }^{180}$ of the supposed trial before the people-

This is in itself the main procedure; but, as is shown by the committal of it to officers mostly of inferior station, and by other

198 Livy, xxxix.'18, 5.

190 Ibid. p. 153.

17 Strafrecht, p. 152. 
indications, ${ }^{181}$ it is as a general rule a formal process directed against accused persons who have practically already been found guilty.

I think that it is difficult to read with an open mind Livy's account of the Bacchanalian conspiracy without being convinced that this explanation ${ }^{162}$ will not serve. The obvious meaning of Livy is that the more guilty Bacchanalians, whether Romans or not; were put to death by the consuls on the strength of the powers which had been stirred up in them by the decree of the senate, and that the culprits were not allowed to appeal to the people. One turns with relief to Mommsen's masterly exposition of the matter in the first edition of the 'Staatsrecht' (i. p. 124), a passage which has entirely disappeared from the last edition.

In the city likewise the criminal jurisdiction of the consuls under certain circumstances revives. The criminal procedure of the republio in its development brought about the practical abolition of the death penalty for Roman citizens; but it was never forgotten that the full imperium included the unlimited right of life and death over the citizen, and that the magistracy, fettered by one law, may be reinstated in its old omnipotence by another law or by what is equivalent to law. This is undoubtedly the case when the chief magistrates were commissioned by special decree of the people to exercise their suspended power for a particular category of crimes. But even when only a senatus consultum to this effect is issued there is frequently ascribed to it the force of a privilegium, especially where delay would be dangerous. Such suspensions of the right of appeal are by no means rare ${ }^{183}$ in the last times of the republic and under the early principate, and. though the strict law was thereby infringed, and the consul was even sometimes held responsible for the infringement, yet in practice prescription pronounced rather in favour of the legality of the action.

After reference to the case of Antony's action against the pretended Marius in 44 B.c. (which ought, as I believe, to fall under another category) he concludes-

One common feature is observable in all these cases-that is, that the consular criminal jurisdiction appears only when provocatio is rightly or wrongly set aside, and never as a preliminary to appeal.

Mommsen seems to me at no time to have sufficiently appre-

181 The 'other indications' are explained in the note by a somewhat irrelevant quotation from Plautus, Capt. 475 :

'De foro tam aperto capite ad lenones eunt,

Quam in tribu aperto capite sontes condemnant reos.'

${ }_{182} \mathrm{It}$ is fair to observe that later on in the book (Strafrecht, p. 258, note) Momm. sen speaks of the maintenance of provocatio under the Bacchanalian commission as only a possible supposition.

${ }^{183}$ Among the cases referred to in the note comes that of the Bacchanalians, of which be remarks that ' the proceedings took place in the first instance in Rome, and therefore must have had the suspension of the right of provocatio as their necessary condition.' He includes under the same head the execution of the Catilinarians, which I should get elsewhere. 
ciated the difference between the cases before and after the law of $\mathrm{C}$. Gracchus-ne de capite civium Romanorum iniussu populi iudicaretur. ${ }^{184}$ Otherwise his analysis of the proceedings of these special commissions, as presented in his earlier work, is clear and convincing, and it is to be regretted that he should have abandoned the position which he there took up.

I will now attempt to sum up, for the sake of clearness, the various principles which govern the several proceedings, and to give to each case what appears to me to be its proper place in the system ; the order will be as follows :-

1. First we have the category represented by the proceedings against the murderers of Postumius, against Tubulus, against the vestal virgins in 114 B.c., and against Servilius Caepio. Here everything seems to be regular; the people by a legislative act restores to the magistrate his full right to punish, or sets up a temporary commissioner with similar rights, that he may act in specified cases on his own judgment, or with such assessors as be may please, with full power of life and death, and with facilities for previous arrest, which will enable the sentence to be carried out.

2. Next follow cases in which the people seeks its remedy against the offender, not by reverting to the ancient and arbitrary powers of the magistracy, but by calling into temporary existence a tribunal similar to the standing jury-courts, the recognised machinery for ordinary justice in the later republic. In the cases in question this machinery is specially directed against a particular offender or group of offenders. Though in form it is still recognised that the function of judgment belongs to the magistrate, in practice his power is here reduced within very narrow limits. The people itself prescribes the punishment which it chooses to visit on the offenders, but makes that punishment conditional on the result of the quacstio of the magistrate as to the facts, and in his decision of the issue he is bound by the advice of his jury. The magistrate has in reality only to announce the verdict of the jury, and thereupon the punishment becomes due. The most important practical difference between this class of trials and the first is that there is here no provision for previous arrest, and so the condemned can always 185 escape by exilium. The procedure must be examined more at length in connexion with that of the quaestiones perpetuac. Here I will only say that I should place in this category the Mamilian (110 B.c.) and Varian (90 в.c.) com-

184 As quoted in Cic. Pro Rab. perd. 4, 12.

12s Mommsen (Strafrecht, p. 199, n. 2) believes that death was actually inflicted on Q. Varius when he was condemned under his own law in 89 B.c.; but I do not think that this is proved. Cicero indeed sags (De Nat. Deorum, iii. 33, 81) that Varius 'summo cruciatu supplicioque periit,' but this may well have been one of the deeds of Sulla's first restoration in the following year.

voL. XVI. - No. LXII. 
missions, the trial of Clodius (61 B.c.), that of Milo (52 B.C.), and that of the assassins of Caesar (43 B.c.)

3. The cases of the Bacchanalians, of the publicani of 138 B.c., of the women accused of poisoning, ${ }^{186}$ and of the adherents of Tib. Gracchus-of whom Valerius Maximus (iv. 17, 1) expressly says, quum senatus consulibus mandasset ut in cos more maiorum animadverteret-seem to me to find a sufficient explanation in the passages which I have quoted from the first edition of the 'Staatsrecht.' The functions exercised by the magistrate are those of a judge, and his powers are precisely the same as those granted to him in the instances which I have placed in my first category, only here they have not been conferred by the people but stirred up by the action of the senate. I should agree that such action was a usurpation on the part of the senate, just as was its practice of granting dispensations. ${ }^{187}$ Polybius ${ }^{188}$ clearly thought that if the senate wished any such powers to be exercised it ought to go to the people to get them. Nevertheless, the practice was no doubt convenient in the presence of wide-spread and dangerous crime, and it was acquiesced in so long as only ordinary criminals were involved. The attempt to apply the procedure to political offenders led the Romans to protest and to quash the precedents. They did this by the law of $\mathrm{C}$. Gracchus ne de capite cirinm iniussu populi iudicaretur. This law appears to have been declaratory and retrospective; for Popillius, the consul who had acted against the Gracchans in 132 B.c., is said to have been the person aimed at, and he was in fact condemned and sentenced. ${ }^{189}$ It must then have clearly prohibited such judicial proceedings as those in which Popillius had engaged; and as a matter of fact none such seem to have been attempted thenceforth except by express decree of the people.

4. Cicero ${ }^{190}$ acknowledges the obligation of Caius Gracchus's law, and claims that it will not be traversed by the execution of death or of perpetual imprisonment on the Catilinarians. This seems to indicate a clear distinction between the action of Cicero and that of Popillius, against which the law of Caius Gracchus was directed. In what did the distinction consist? Cicero himself in the next sentence supplies the answer. His action was not a judicial execu-

${ }^{146}$ If these be admitted into the list at all (see above, p. 252).

197 Explained by Asconius in Comelianam, 57.

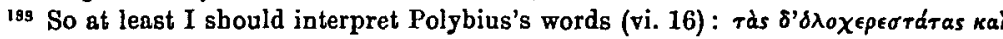

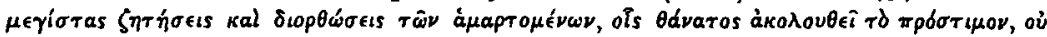

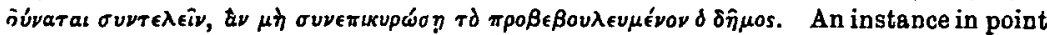
would be the authorisation by the people which the senate obtained in the case of the Campanians (Livy, xxpi. 33).

Mommsen has another explanation (see above, p. 248), taking Polybius to refer not to the appointment of a commission, but to the trial of an individual case on appeal. I do not believe that the senate bas anything to do with appeal cases.

Iro See Plutarch, C. Giracch. 4, and Cic. De Domo, 31, 82.

190 Cat. iv. $5,10$. 
tion of citizens, but an act of war against enemies. Mommsen in a passage already noticed (above, p. 238) has clearly explained that the perduellis has by his own act placed himself in the position of a foreign enemy, and so has ceased to be a citizen. The senate fell back upon the doctrine, when they were deprived of the power of erecting a judicial tribunal. They simply passed a decree ' that the consuls were to see to it that the state took no harm,' and the consuls thereupon put in exercise their full power against those who had constituted themselves hostes. The first person ${ }^{191}$ against whom the new method was employed was Caius Gracchus himself, and Opimius, the consul who put him to death, was acquitted by the people when brought to trial for his act. Saturninus and the Catilinarians fell in the same way; and on similar grounds the consuls of 44 B.c., Antony and Dolabella, put to death the false Marius and other rioters after Caesar's death without even waiting to be reminded of their duty by the senate. In the concluding volume of the 'Staatsrecht' (IIr. ii. 1243), published as lately as 1888, Mommsen sums up the matter admirably.

The quasi-dictatorship instituted by the senate is treated, broadly speaking, as a portion of constitutional order, introduced in the time of the Gracchi; not only did the populares occasionally make use of it when they had the upper hand in the senate, but Caesar and the Caesarians themselves treat it as valid in law, even where they blame the application of it. During the last century of the republic the prerogative of the senate to exercise over the citizens the rights of war, in the old unlimited sense of the period of the kings, was never seriously disputed.

These doctrines require restating in order to complete the picture of the various forms in which the state takes action against offenders. Mommsen in his present work, if be does not expressly retract the doctrine set forth in the 'Staatsrecht,' at any rate expresses it with more hesitation and less clearness. The only point, however, in which he seems to me directly open to correction is that he expressly identifies (p. 258) the action of Popillius in 132 B.c. with that of Opimius, Marius, and Cicero. Mommsen is debarred, by the theory which he has now adopted of the Bacchanalian trials of 186 B.c., from explaining Popillius's executions by the precedent of that year. On the contrary Popillius (who certainly did not

191 Though Appian is indecisive, Plutarch's account makes it clear that the 'ultimum senatus consultum' was not passed against Tiberius Gracchus in 133 B.c. The action of Nasica against Tiberius himself (as distinguished from that of Popillius against his adherents) was what Mommsen elsewhere (Staatsrecht, iii. p. 1241) calls ' unmittelbar nothwehrsrecht,' undertaken by one who constituted himself for the occasion a 'tumultuarius miles.' See also Mommsen, Röm. Forsch. ii. p. 247. Livy's statement in the conrse of his story (iii. 4, 9, and vi. 19,3) that such decrees were issued two or three hundred years earlier (in 464 and 384 B.c.) cannot be considered historical. 
allow provocatio) has to be made a precedent for Opimius and the rest. Mommsen does not seem sufficiently to appreciate the difficulty that the law of Caius Gracchus is thus represented as so badly drawn that, though expressly directed against certain pro ceedings, it failed to prohibit an exact repetition of those proceedings in future. It is surely much more natural to suppose that Caius Gracchus effectually barred one path, but that the Optimates found out another -that what he forbade was a judicial trial, and that what they substituted was administrative action.

The difference between these two views of the Sempronian law may be illustrated by an incidental reference to Caius Gracchus's measure in a discussion of perduellio later on (p. 590) in the 'Strafrecht.' The passage is worth quoting for its own sake.

The more heinous species of this crime is essentially distinguished from all other crimes by the circumstance that in perduellio the perpetrator by the very act passes out of the citizen ranks into the category of public enernies. When from this premise the consequence is drawn that all judicial proceeding is therefore unnecessary, and that the rights of war may be put in force, this is a party doctrine and contravenes law. But even under the observance of the Sempronian law, which expressly prescribed the necessity for the trial for treason, the effect of the verdict therein pronounced is not condemnatory, but declaratory, and when judgment is given the consequences of the crime are antedated to the moment of its commission. This is manifest from the circumstance that those consequences ${ }^{192}$ which can take effect after the death of the criminal are not here, as in all other crimes, barred by his death between the crime and the trial.

If the Sempronian law really did, as Mommsen here assumes, 'expressly prescribe the necessity of a trial for treason,' ${ }^{193}$ I cannot see how Cicero could, with any plausibility, have argued as he does-that C. Caesar has not hesitated to pronounce on these men in spite of the law of Gracchus, 'because he knows well that the Sempronian law relates to Roman citizens, and that the man who is an enemy cannot by any possibility be a citizen,' ${ }^{194}$ nor again can I imagine why Sallust the Caesarian should have refrained

${ }^{102}$ On p. 592 Mommsen further explains that not only the testament of the 'perduellis,' but all his dealings with his property from the moment of his crime are null and void.

${ }^{109}$ I do not agree with Mommsen (Strafrecht, p. 633, n. 2, and p. 258, n. 1) that this law of Gracchus is to be identitied with his law 'ne quis iudicio circumveniretur,' which was afterwards taken up into the legislation of Sulla (see Cic. Pro Clu. 54, seq.); but that identification, if accepted, surely raises another objection to his present interpretation. The crime for which Cluentius was tried was undoubtedly that of corrupting a iudicium; and a law directed against that particular crime must assume that a iudicium of some sort has taken place. If, as Mommsen now believes, the point of Gracchus's law was to prevent a trial being dispensed with, its short title ought rather to have been ' ne quis sine iudicio circumveniretur.'

198 Cic. Cat. iv. 5, 10. 
from introducing a refutation of this published statement, if it really admitted of refutation, into his master's speech.

It is now time to consider the introduction of a fresh element which revolutionised the administration of the Roman criminal law; this is the adaptation ${ }^{195}$ to public needs of the forms of the private lawsuit, with its reference of disputed questions to the decision of a juror or jurors ; in other words, it is the growth of a system of standing jury courts for criminal charges. The new system ${ }^{196}$

is not originally invented as a substitute for the public penal procedureit does not even take its rise from any notion of crime-but is rather in its inception merely a private suit, vested with special privileges on account of its overwhelming public interest, and differs from numerous other similar ones ${ }^{197}$ only in that the presidency of a magistrate is extended to the whole proceedings.

The innovation has its origin in the difficulty which beset Rome, as her empire extended, of preventing her magistrates from making a profit of their official position at the cost of the subject peoples. The recovery at law of moneys so exacted is known as res repetundae.

The repressive measures (says Mommsen) directed against such practices were not only of the deepest significance politically during the last two centuries of the republic, but likewise, not so much indeed in their intention as in their development, proved the starting-point for the transformation of the penal law generally. ${ }^{198}$

We first hear of a trial for repetundae in the year 171 B.c. The people of both the Spanish provinces had complained to the senate of the exactions of their governors, and the senate directed them to sue for recovery before one of the praetors, who was to nominate in each several case five private senators as recuperatores. No decree of the people seems to have been thought necessary; the senate merely allotted the duty of investigating the matter to a particular praetor, with instructions as to his procedure. To carry out these instructions must have been within the power of the magistrates as such.

We now come face to face with the main difficulty of such cases, which presents itself in all its fulness in this the most primitive instance. The recovery of money is the sole object with which the court has to deal, and one would have thought that with the

ios See Strafrecht, p. 343.

196 Ibid. p. 202.

197 I have taken the liberty of sltering Mommsen's expression. He says 'iudicia. publica.' This is quite correct if 'publicus' be taken in its original sense (which he has explained on $y$. 192) as equivalent to 'popularis'-i.e. a case in which a common informer may sne ('cuilibet ex populo experiri licet '). It is, however, unfortunate to use the word here, as it at once recalls to the mind the later sense (e.g. Lex Iulia Municipalis, verse 118) of a trial before a jury court.

183 Strafrecht, p. 705. 
recovery of the money the case was at an end : but no-we are distinctly told ${ }^{199}$ that the condemned went into exile (precisely as Polybius ${ }^{200}$ describes contemporary criminals doing in the comitial trial), the one to Praeneste, the other to Tibur. In the comitial trial their reason for thus renouncing the Roman citizenship is obvious; they go to escape death. But why should failure in a civil suit lead to the same result?

The separation, ${ }^{201}$ in form voluntary, from the citizenship of the ruling community, and therewith the loss of political existence, already occurs as the result of the sentence of the recuperatores, which paved the way to the Calpurnian law, and after this it is the regular end of a condemnation for repetundae.

It is easier to state the fact than to account for it. Mommsen suggests that the exactions were probably on a colossal scale, and that even simple restitution may have been enough to bring about bankruptcy and its consequences. ${ }^{202}$ The goods of the condemned would of course be seized in any case, ${ }^{203}$ but possibly this may have been effected in some less disgraceful way on the man whose name had been blotted out by death or exile than on the living Roman citizen. ${ }^{204}$ Possibly, likewise, the trial may have shown that there was evidence to go to the people on a charge of perduellio. If so the danger lay at the door that some tribune might seek to advertise himself by taking up the case, and if once it came on appeal before the people the verdict of the recuperatores on the pecuniary question would act as a praeiudicium likely to influence the minds of the voters in the iudicium capitis. The disgrace of condemnation on a capital charge was avoided by the timely exile of the parties, though that exile anticipated, so far as material consequences were concerned, the worst that was likely to happen to them even had the people voted against them.

The case of the Spanish governors was followed ${ }^{205}$ by a succession of similar ones, in which the guilty persons were condemned under arrangements made by the senate for each occasion. At length, in the year 149 B.c., a tribunician law of L. Calpurnius Piso Frugi instituted the first standing court for such trials. We know from a reference in the fragments of the 'Lex Acilia' (verse 23) that the procedure under the Calpurnian law was by the forms of the civil actio sacramenti. This Piso is

149 Livy, xliii. 2.

200 See above, p. 249.

so1 Strafrecht, p. 730.

202 It is doubtfol whether at this late date these would include the old 'addictio.' Mommsen (ibid. p. 7.27) thinks that they would not.

${ }_{203}$ Zumpt (Criminalrecht, n. i. p. 18) has a strange notion that they escaped pay. ment altogether; but this is quite unfounded. The most we can say is that if they succeeded in smuggling away any valuables into their new homes they would probably retain them unmolested; compare the advice given by the emperor Domitian to Licinianus; see below, p. 284.

$20+$ See Strafrecht, p. 727.

aus Tbid. p. 708. 
supposed to be the author of another 'Lex Calpurnia,' which extended the scope of condictio, an actio in personam, whereby restitution could be compelled of money or other goods the property in which had actually passed, ${ }^{206}$ and Mommsen ${ }^{207}$ argues with some probability that he applied this system ${ }^{208}$ to cover the claims of the allies and subjects of Rome. Mommsen further points out ${ }^{209}$ that the law avoided throwing on the accuser the burden of proof as to extortion by forbidding all gifts, whether freely offered or not. This would make condictio a proper instrument for their restitution, whereas if the actio repetundarum had been assimilated to the actio furti, which from a moral point of view would not be unnatural, the accuser would have been obliged to prove a corrupt intention.

Passing over the 'Lex Iunia,' of which we know nothing but the name, we next come to the law of 123 B.c., of which large fragments are preserved to us on a bronze tablet, now in the Naples Museum. Mommsen ${ }^{210}$ calls it, as do most modern writers, the 'Lex Acilia Repetundarum,' on the ground that in the mention of such laws which we find in Cicero the Acilian immediately precedes the Servilian law. Mommsen admits that this is slight evidence; and he sees quite clearly that, though the name of Acilius may have been in the preamble, the law is really part of the legislation of Caius Gracchus ${ }^{211}$ (just as the 'Lex Aurelia' of 70 B.c. is really part of the legislation of Pompey). It is in fact the very law, ascribed to Gracchus by the historians, by which the jury courts were trans-

:06 If I deposit my plate or railway stock at my banker's the property in them remains with me; under Roman law I could recover them by 'vindicatio,' an 'actio in rem.' If I deposit my money with the same banker the 'ius in re ' passes to him ; its restitution, if refused, gives rise to an ' actio in personam.' At Rome I could have got it back by 'condictio.' For an ingenious explanation of the apparent inconsistency that there can be a ' condictio rei furtivae,' though in that case, under Roman law (which knows nothing of ' market overt'), the property never passes, see Strafrecht, pp. 716, 757.

202 Ibid. p. 708. See also p. 202 , n. 1 , and p. 343, n. 1 .

${ }_{008}$ There is, however, the difficulty, which Mommsen does not notice, that Gaius (Inst. iv. 20) seems to set down 'condictio' as a fresh 'legis actio' parallel to and exclusive of the 'actio sacramenti.' We should expect, then, to find in the Lex Acilia 'quod cum eo Lege Calpurniâ conäictione actum siet,' whereas the text has 'sacramento.' Gaius perbaps did not mean to imply so much innovation in the procedure by way of 'condictio' as his words seem to suggest. The whole question is very obscure.

Strafrecht, p. 716.

210 Ibid. p. 708 , n. 6.

$\because .1$ Ibid. pp. 708, 728. It would seem from the completeness of the regulations about the 'album iudicum' that, when this law was passed, the 'quaestio repetundarum' was the only standing jury court for which it was necessary to provide. In that case we must suppose that the 'quaestio ' for conspiracy (' ne quis indicio circumveniretur') and that for murder ('de sicariis'), if this too be rightly attributed to Gracchus, must have been subsequent to the present law, and in their regulations as to the constitution of the juries must have followed the lines here laid down. 
ferred from the senate to the equites. If this be conceded it matters little by what name we call it. ${ }^{212}$

This law has been admirably reconstructed from the fragments (though of course with many gaps) by the labour of Mommsen and others ; and it constitutes our chief authority for the jury trials for repetundae. It is directed exclusively against magistrates, senators, and their families. It allows any one, not being a Roman citizen, to delate such a person and sue him for double ${ }^{213}$ the value of whatever has been ablatum, captum, coactum, conciliatum, aversum. The private man is not only, as in purely civil suits, the accuser, but he relieves the magistrate from the task, which under the older style of quacstio had fallen on him, of collecting the evidence and establishing the proof. ${ }^{214}$ Neither magistrate nor jurors may question witnesses or make any remarks on the evidence. ${ }^{215}$ The magistrate has now only to summon the jury, under methods carefully prescribed in the law, to receive their votes, and, if the majority condemn, to pronounce the verdict fecisse videri. He is then to require the condemned man to find sureties for the payment of the damages, or, if he fail to do so, he is at once to enter into possession of his whole estate, and sell it in the name of the Roman people, which will hold the proceeds in trust for the aggrieved parties, amongst whom they are eventually apportioned. Next is to follow the litis aestimatio, or assessment by the jury of the value of the object in dispute under each count. When the object is money the question is simply its quantity; when it is anything else the value in money must be calculated. The whole is thus brought ${ }^{216}$ under the rule of private actions, that every condemnation must be for a specific sum of money. On the other hand it is possible in these actions for repetundae (though this is not allowed in strictly private suits) to combine a number of charges into a single accusation $;{ }^{217}$ in this respect the jury trials follow the analogy of the multae irrogatzo of the tribune, in which, as we gather from Cicero, ${ }^{218}$ the charges may be a most miscellaneous collection.

212 Mommsen's view, of the justice of which I am fully convinced, implies the rejection of Plutarch's statement $(C$. Gracch. 6, 1) that Gracchus himself had the selection of the jurors, which is quite inconsistent with the text of the law. If we consider the hopeless confusion of the second-hand historians as to what was in the law, and the still greater errors in their account of the Lex Aurelia of 70 B.c., it does not seem too bold to say that Plutarch made a mistake. Zumpt, of course, will not hear of such a thing, and accordingly puts our fragments some years later than Graechus. Mommsen does not think it worth while even to mention the discrepancy with Plutarch; I do not know that he is to be blamed.

213 That this is an innovation is proved by verse 59 , where only single damages are allowed for acts committed before the passing of this law. Mommsen says (Strafrecht, p. 728) that 'it can be as little doubted as it can be little proved' that Sulla reverted to single damages, and that the Lex Iulia of Caesar's first consulohip again doubled them. I own that I can see no reason for this conjecture.

${ }^{214}$ Strafrecht, p. 393.

216 Ibid. p. 724.

${ }^{215}$ Toid. p. 422.

213 Toid. p. 723.

${ }_{219}$ Pro Rab. perd. 2, 7. 
Thus the litis aestimatio becomes a complicated and serious matter. Under subsequent laws, if not under that of Gracchus, we find that numerous offences, not strictly bearing the character of extortion, may come to be taken account of in the litis aestimatio, and so swell the amount of damages. ${ }^{219}$ If, for instance, a governor trades in his province, if he buys slaves, if he appropriates state property (which is really peculatus), or if he transgresses the bounds of his province (which is maiestas), he is frequently described as contravening various 'Leges Repetundarum,' and any such acts may be alleged against him when the assessment is uncler consideration. We even find a case where corruption as a juror at Rome is allowed to be reckoned amongst the offences for which a person condemned for repetumdae has to pay damages. Cicero ${ }^{220}$ tells us that in this case great efforts were made by the accuser to bring this capital charge into the assessment (ut lis haec capitis aestimaretur), and he observes further that such charges are often included, so carelessly that the same jurors have been known to acquit a man when the very same acts which they had ascribed to him in the litis aestimatio were alleged against him as a substantive charge on a subsequent trial for maiestas. It is evident that such a fresh trial was necessary before the extra penalties attaching to maiestas could be inflicted.

The subsequent 'Lieges Repetundarum,' that of Servilius Glaucia, of Sulla, and of Caesar, as consul in 59 B.c., can be sufficiently dealt with in incidental references, and it will be best to pursue the really difficult question raised above (p. 262)-namely, what happened to persons condemned for this crime, and how are the practical consequences of condemnation to be reconciled with the record of the penalties prescribed by law? There is no statement in the fragments preserved to us of the 'Lex Acilia' of any penalty other than the pecuniary one attached to condemnation for repetunclae. We see, however, provision made (verse 29) for the case of the accused going into exile ${ }^{221}$ before the trial is over, and among the rewards for the accuser is, under certain circumstances,

219 Strafrecht, p. 720. It is a very different thing when Zumpt (Criminalrecht, II. ii. 333) exaggerates this into the statement that 'after the condemnation of the accused there followed at the litis acstimatio the question whether a heavier punish. ment or only a pecuniary penalty was to be exacted.' He thinks that the Lex Iulia instituted for the first time a separate court for ' repetundae,' whereas before that a single court took cognisance of all official misdemeanours (ibid. pp. 322-44). This notion, that it was the business of a Roman jury to decide what punishment should be inflicted, vitiates all Zumpt's theories. Mommsen treats the hypothesis with silence, which is perhaps all that it deserves.

${ }^{220}$ Cic. Pro Clu. 41, 116. Mommsen, by the way, makes sense of an otherwise quite inexplicable passage by reading here 'si quae in eum lis capitis illata est, non inviti admittunt' instead of 'non admittunt,' which is absurd.

231 There appear's (Cic. Pro Quinctio, 19, 60) a similar provision in the praetor's edict for the seizure of the goods of a man who 'solum verterit exilii causa,' in order to avoid the consequences of bankruptcy. See Strafrecht p. 70, n. 1. 
the attainment of the Roman citizenship in the tribe of the condemned man (verse 77): If the full text had remained to us, we should expect to find that this reward was limited to cases where the guilty person had actually gone into exile, and so left a gap in the ranks of the Romans. In other instances, at any rate, where a new status is given to a successfnl accuser it is apparently always by substitution of him for the person whose condemnation he has effected..$^{222}$ In any case, as bas been pointed out in the passage of Mommsen quoted above (p. 262), most of those condemned did actually go into exile. In the list in Cicero's speech 'pro Balbo' $(11,28)$ there occurs as having become a citizen of Smyrna Rutilius Rufus, who was certainly condemned (92 в.c) for repctundae. T. Albucius, who animo aequissimo Athenis exul philosophabatur, ${ }^{223}$ was accused by the Sardinians, ${ }^{224}$ and this can hardly have been for anything but extortion. The same is probably the case ${ }^{225}$ with L. Lucullus, father of the famous general, in 102 B.c.; he retired to Heraclea, ${ }^{226}$ though it is not expressly said that he became a citizen of that state. In the case of Cn. Dolabella, Verres's chief, exile seems to be implied by the reference to his children, quos tu miseros in egestate et solitudine reliquisti, and by the words condemuato et eiccto. ${ }^{227}$ Verres himself, as is well known, went into exile to Massilia. The load of misdeeds which would be proved against him in the litis aestimatio would doubtless have led to 'capital' actions for maiestas and peculatus, if he had not thus forestalled them. C. Antonius, Cicero's colleague in the consulship, after his condemnation for his extortions in Macedonia retired to Cephallenia, ${ }^{228}$ where as an exile he proceeded to found a new city, but gave it up when he was recalled home. Cephallenia was a libera civitas, ${ }^{229}$ whose franchise Antonius could conveniently take up. Besides these we have two cases of suicide of persons accused of repetundae, Silanus Manlianus (about 140 в.c.) ${ }^{230}$ and Licinius Macer, ${ }^{231}$ who was tried before Cicero as praetor repetundarum in B.c. 66. Of the fate of others, probably of most of those condemned for repetundae, we have no information; but these instances ${ }^{232}$ are sufficient to justify Mommsen's statement as to the general effect of condemnation, though the circumstance that it was worth while later on ${ }^{233}$ especially to add infamia and expulsion from the senate

272 Mommsen (ibid. p. 509) gives instances to the point. We may perhaps add the reward proposed for the slave who betrayed his master in the proscriptions-кal

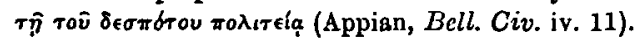

${ }^{223}$ Cic. Tusc. v. 37, 108.

$=+$ Cic. in Verr. Div. $19,63$.

22s See Zumpt, Criminal-Prozess, p. 475.

226 Cic. Pro Arch. 4, 8.

$=2$ Cic. in Verr. i. 30, 77, and 39, 98.

2z8 Strabo, x. 456.

220 Val. Max. v. 8, 3.

$\simeq$ Pliny, iv. $\$ 54$.

al Ibid. ix. 12, 7.

252 I must express my obligations throughout this article to.Zumpt's catalogues of trials, in the present instance to that given in the Criminal-Prozess, pp. 468-558.

23 Mommsen says (Strafrecht, p. 709) by the Lex Servilia of Glaucia. He 
to the pecuniary penalty seems to show a wish to sharpen the inducements to retire from the Roman state.

To set against all these we have one case which points the other way. 'L. Lentulus, a consular,' says Valerius Maximus (vi. 9, 10), 'after being overwhelmed by a charge of repetundae under the Caecilian law, was created censor along with $L$. Censorinus.' The censorship of this Lentulus was in the year 147 B.c., and his consulship had been nine years earlier. The commentators alter 'Caecilia' (no 'Lex Caecilia' being known) into 'Calpurnia,' and suppose that Lentulus was condemned by a jury court immediately after the passing of Piso's law in 149 B.c. This is possible, but by no means certain ; it seems more probable that the conviction of Lentulus followed close on his consulship, and was the result of a special commission. The passage, if trustworthy, seems, however, to show that at one time it was possible to be condemned for repetundae without damage to a political career. The case of C. Porcius Cato in 113 B.c is famous for the petty sum at which the damages were assessed-about $80 l$. It seems strange that he should have become an exile for so trifling a matter. Yet Cicero mentions him in his list in the 'Pro Balbo' as having become a citizen of Tarracona. The case has been used to support two opposite conclusions. On the one hand it has been argued that the fact that Cato did go into exile for so small an infraction of the law shows that 'capital' penalties must have attached to condemnation. Zumpt, on the other hand, believes that Cato must have been exiled as the result of some subsequent misdeeds, punishable as maicstas, and thinks that the circumstance that he beld a position giving opportunity for such acts shows that no infamia or disqualification for office resulted from his conviction for repetundae. The whole matter is very obscure, and we should never have heard of it if $\mathrm{C}$. Cato had not served as a favourite illustration ${ }^{234}$ of the scrupulous severity of equestrian juries, even where the wrong done was slight.

On the whole it appears that there is no certain case of a person condemned for repetundae remaining in Rome since the standing jury court was first instituted by Piso Frugi in 149 B.c., and

gives no evidence, and I know of none save, possibly, the apparent connexion of the Lex Servilia with the 'calamitas senatoris' in Cic. Pro Balbo, 24, 54. Mommsen believes that here too Sulla abolished and Caesar renewed this penalty. Yet Cicero (in Verr. ii. 31) seems to assume that in 70 B.c. the question whether Verres will remsin in the senate and serve on juries depends on whether he is found guilty for repetundae or not. The only thing we know for certain is that this penalty survived in the Lex Iulia, as administered under the principate (Strafrecht, p. 729). Cicero uses ' blood ' and 'life' quite as freely when defending Flaccus against a charge of extortion as he does on behalf of any of his clients who are accused on 'capital' charges.

at Cic. in Verr. iii. 80, 184, and elsewhere. For Zumpt's opinion on the case see Criminal-Prozess, p. 471. 
only one, and that resting on the frail authority of Valerius Maximus, after the first occasional trial before recuperatores in 171 B.c. What it was that drove all these oftenders into banishment, must remain an unanswered question; and the same diffculty occurs with the self-exile of persons in danger of bankruptcy (see above, p. 265 n. 221). I do not wholly despair that some longlost text or inscription may hereafter be discovered, which shall show that consequences, now unknown to us, luat extending far beyond the seizure and sale of goods, were connected in some indirect way with these convictions; and that somewhere in these consequences is to be found the missing motive for the renunciation by the convicts of their Roman citizenship. All that can be said at present is that there is no evidence in support of so satisfactory a solution, and that the puzzle must be left where it stands.

I pass with less feeling of uncertainty to the subject of capital trials before jury courts, though it is here, more than anywhere else, that I feel myself unable to follow in the track of my guide. I will first attempt to sketch the history and nature of these trials, as I read them in the light of the ancient authorities, and will then state as clearly as I can the points in which I differ from Mommsen in the interpretation of those authorities.

The system of jury courts, developing its procedure from private law and its consequences from public law, which began with trials for repetundae, was gradually extended to cover other crimes. It is a doubtful point how many standing courts existed before the time of Sulla, but all were talien up in his legislation. In some cases the 'Leges Corneliae' of Sulla remained the nucleus of statute law, round which the lawyers of the principate built up their system of jurisprudence; ${ }^{235}$ in other cases the 'Leges Corneliae' were remodelled into 'Leges Iuliae' either by the dictator Caesar or by Augustus. The period from Tiberins to Diocletian was, as Mommsen points out, ${ }^{236}$ barren of fresh legislation. 'On the century of active legislation extending from Sulla's dictatorship to Augustus's death there follow, introduced by the paralysation of all free movement under the rule of his stern successor,

235 Mommsen has an interesting passage (Strafrecht, p. 5331) in which he points out the defeets of this system, compared with the work of the same men in the field of civil jurisprudence. Especially, he says, there is nothing in the Roman criminal law which will bear comparison with the treatment of 'iniuria' as a civil wrong, 'a masterpiece not only of jurisprudence but above all of legal practice, and to this day a humiliating proof that the progress of humanity is always just as much a retrogression.' It is a difficult question whether Sulla treated 'iniuria' as merely a civil wrong. In the next paragraph I have assumed this to be so. There is no contemporary evidence for a criminal ' quaestio de iniuriis,' and the references in the later jurists to the Lex Cornclia de Iniluriis are by no means decisive. See Strafrecht, p. 785.

230 Strafrecht, pis. 130, 529. 
three centuries of stiff and senseless retention of the established order, the evil results of which will be brought out when we come to the apportionment of penalties in the fifth book.' These evil results ('Strafrecht,' p. 1038) are found to consist mainly in the disappearance of the rule of law from the penal jurisdiction and the reference of everything to the arbitrary discretion of the judge or of the head of the state.

In the last generation of the republic under the Cornelian system theft, adultery, with probably other gross offences against morals ('Lex Scantinia'), and injury or insult, directed against person or property, are still 'private crimes,' and are dealt with by the urban praetor under the forms of a private suit, in which, however, we must include the popularis actio, brought by a common informer for the recovery of the fine prescribed. On the other hand we have criminal jury courts for murder (quaestio de sicariis et veneficis); which includes arson and perhaps barratry, ${ }^{237}$ for: conspiracy to convict the innocent (ne quis iudicio circumveniretur), for treason (maiestas), for organised conspiracies to influence elections (de sodaliciis, after 55 B.c.), for embezzlement of state money (peculatus), for violence, rioting, and intimidation (de vi), for forgery and fraud (de falsis), for ordinary corrupt practices at elections (de ambitu), for extortion (repetundarum), and finally for malicious or collusive prosecution (calumnia and praevaricatio), charges which were dealt with by the jurors. who had tried the case out of which they arose. Each fresh quaestio is looked upon as bringing for the future a new range of offences under the direct cognisance of the will of the people as expressed in its laws and enforced by its courts. Mommsen happily quotes ${ }^{238}$ Cicero's remarks on the effect of the 'Lex Cornelia de falsis,' ut quod semper malum facinus fuerit, eius quaestio ad populum pertineat ex certo tempore.

Except in the last three cases mentioned (ambitus, repetundae, and abusive prosecution) all ${ }^{239}$ the charges included in the liet are described in our authorities as 'capital,' and of many of them we find it recorded in the later jurists, Lex Cornelia aqua et igni interdici iussit. That capital consequences should be attached to condemnation in that which is by origin and tradition a private suit between citizen and citizen had nothing in itself shocking to the Romans. In the old days of self-help such result would often ensue from a 'private crime,' and there is nothing to prevent the people from attaching what consequences it pleases to condemnation by this or that set of jurors. Accordingly we find Ulpian ${ }^{240}$ quoting the 'Lex Cornelia de Sicariis,' ut praetor QUAERAT DE CAPITE eius qui cum telo

${ }^{237}$ Sirafrecht, p. 646.

228 Ibid.p. 670 ; Cic. in Verr. i. 42, 108.

229 It is possible that 'peculatus' should also be included among the exceptions, but I think not. See Strafrecht, pp. 769-771.

210 See Strafrecht, p. 629. 
ambulaverit hominis necandi causa, and Cicero ${ }^{241}$ quoting the law against conspiracy which Sulla borrowed from Gracchus. (quae tune erat Sempronia, nune est Cornelia), DE CAPITE EIUS QUAERTTO.

On the other hand there is no trace in all the voluminous evidence supplied by Cicero's speeches that a single Roman was ever put to death in his time by regular course of law. Without exception the persons condemned on 'capital' charges go into exile. This again is no new thing; we have seen (above, p. 249) that it was the fashion in Polybius's time for persons to save themselves from death 'by pronouncing voluntary exile against themselves and finding refuge in a neighbouring state.' There is this difference, however, that whereas under the régime of trials before the people it was possible, if the tribunes permitted, for the magis-

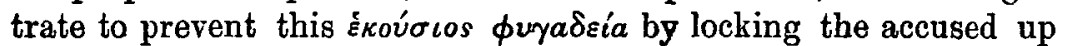
beforehand, the private accuser who appears under the jurycourt system has no such power, ${ }^{242}$ and is obliged to content himself with a summons, which has as little effect on impeding the flight as had the trumpet blast by which M' Sergius was to summon 'the wicked Titus Quinctius Rocus' (see above, p. 251).

What is it that happens when a man goes into exile? Here we get a most complete and logical account from Cicero in his speeches 'Pro Caecina' and 'De Domo.'

I wish (he says), 243 as they are fond of precedents from the civil law, that they would adduce any instance of persons who are deprived by law of Roman citizenship or of liberty. For as regards exile it can be clearly shown what its nature is. Exile is not a punishment, but an asylum and harbour of refuge from punishment. For persons who wish to evade some punishment or some ruin on that account 'shift their ground ' (solum vertunt) - that is to say, take up a new seat and habitation. And so it will be found that in no law of ours has any crime been punished by exile, as it is in other states; but forasmuch as men shrink from the chains, the death, the disgrace which have been ordained for them in the laws, they betake themselves to exile as to sanctuary. If they chose to remain in the stateand abide the weight of the law, they would lose their citizenship only with their last breath; now, as they do not choose this, the citizenship is not taken away from them, but laid down and abandoned by themselves. For since by our law no one can belong to two states at the same time our citizenship is lost then, and not till then, when he who has fled is received into exile-that is to say, into another state. 244

2.1 Pro Clu. 54, 148.

:12 Strafrccht, p. 390. See also ibid. p. 328. The praetor presiding over these courts could apply the magisterial summons, but the right to exercise preliminary arrest seems to have been wanting to him; at least the accused seems always to have been at large, even in the murder trials.'

2N3 Cic. Pro Caec. 34, 100.

${ }^{214}$ It will be remembered that Pleminius was still liable to Roman law, and was actually seized and brought back when he was on his way to Neapolis, but had not jet arrived there (see above, p. 250). 
And again in the 'De Domo,' 30, 78-

No persons condemned on capital charges ever ${ }^{245}$ lost their Roman citizenship until they were received into that state to which they had come for the purpose of 'shifting'--that is, changing their ground. And the authors of our laws compelled ${ }^{246}$ them to do this not by taking away their citizenship, but by forbidding them shelter, fire, and water.

These statements of Cicero are in absolute agreement with that of Polybius regarding the voluntariness of the act, the reasons which a criminal has for performing this act, ${ }^{247}$ and the refuge afforded to him in a fresh state. The only difference is that Cicero can no longer name Tibur or Neapolis, because they have become, since the Social War, a part of Rome, and that he supplements Polybius by explaining that 'the voluntary exile is pronounced by means of the renunciation of one citizenship in the act of accepting another. Curiously enough Mommsen adopts this view of exilium under the Cornelian laws in one case-that of the parricide-but treats it as an exception ; ${ }^{248}$ ' the quaestio, the reference by a general or special law of what is by public penal law a capital crime to the decision of a single juror or a bench of jurors by no means in itself excludes a sentence of death .... The standing commission for murder even under Sulla's ordinances condemned to death the murderer of near kindred.' This is explained in another passage (p. 644, n. 3).

Immediately after the Cornelian law against murder was passed, the accusation set on foot under it of Sex. Roscius for parricide led up to the punishment of death, and death in ancient fashion in the sack, though it is true that it was open to the criminal to withdraw himself from the condemnation by exile.

I should entirely agree with the general statement in the first sentence, and my only objection to the remarks about the parricide

215 The imperfect tense seems to be used because Cicero is speaking throughout this passage of what had been laid down by the wisdom of the ancients-'ius $B$ maioribus nostris . . ita comparatum est.' We must not infer from the tense that Cicero was describing a state of things which had passed away. Such an inference would bring this passage into contradiction with that from the Pro Caecina, where the present tense is used throughout. Mommsen evidently recognises this, for he does not found any conclusion on the use of the past tense here, though it might plausibly have been alleged to support his own view. Both in the Pro Caccina and in the De Domo it would have helped Cicero's argument if he could, without fear of contradiction, have added, ' but all this is ancient history, and, as things are now, men do not lose their citizenship, even when condemned.' That he does not use so tempting a plea is pretty good evidence of facts within the knowledge of his hearers, which prevented his doing so with any plausibility.

246 The phrase 'id ut esset faciundum . . . faciebant' is so awkward that one is tempted 'by the amendment 'adigebantar' (for 'faciebant'), adopted by Zumpt (Crim.-Proc. p. 456).

217 Mommsen (Strafrecht, p. 966) styles it very happily 'die freiwillige, wenn auch widerwillige Auswanderung.' The man finds that 'the climate of Italy does not suit him.' its Strafrecht, p. 942. 
is that I think that they ought to be applied to all criminals convicted on a 'capital' charge. 249

To return to the conception of exilium. It obviously consists of two parts, both equally necessary to its completion. First, there must be the physical withdrawal to some safe place (solum vertere) : secondly, the withdrawal must be exilii causa, with the intention of going not as a visitor but as a settler. Given these two things, the ins cxulandi works automatically; " it realises itself by virtue of the standing treaties without the co-operation either of the community into which the man enters or that from which he retires.' 2.0

Of the physical withdrawal I have already said enough : it was a matter of fact, as to which in each case there can have been little doubt. But it is otherwise as to the intention of the exul. This could only be presumed from his situation or inferred from his words or actions, and he might afterwards say that the inference was wrong, and that he had never really meant to naturalise himself abroad. Cicero practically does this in his speeches after his return from banishment. The Komans had, therefore, to take precautions against such tergiversation. It is said that a member of the duke of Wellington's cabinet, who had resigned office in a pet, wished to withdraw his resignation on the ground that 'there had been a mistake.' 'It is no mistake,' replied the prime minister; ' it can be no mistake; it shall be no mistake.' The Romans retorted in much the same way. They could not deprive a man of

241 The question of what was done with the 'common malefactor' has greatly exer. cised the critics. What happened to the street ruffian who knocked down a peaceful citizen and took his purse? Zumpt thinks that the criminal whose guilt was evident or confessed was dealt with summarily, and never allowed the chance of provocatio or of a jury trial, or of any of the other contrivances for evading the death penalty. This is repeated ad nauseam on page after page in Zumpt; but see especially Criminalrecht, Ir. i. 289, where he says that provocatio ' was very seldom allowed.' This is going much further than Mommsen (see above, p. 251), who holds that liability to previous arrest, not denial of provocatio, befell the 'common criminal.' The whole superstructure of Zumpt seems to rest on no better foundation than a single case (Suet. Aug. 33), by which it appears that in Augustus's time parricides were sewn in the sack only if they confessed, and on a remark of Cicero (Pro Murena, 20, 42) that the 'quaestio peculatus' was a dreary business, 'plena catenarum.' Mommsen (Strafrecht, p. 328, n. 5) disposes of this last by referring it to the public slaves employed as clerks. Mommsen himself in the Staatsrecht (iii. 1242) was inclined to think that under the constitution of Sulla the 'common offender,' caught red-handed, was thrown into prison and strangled (just like Lentulus and his companions in the Catilinarian conspiracy) as a public enemy. In the present work (p. 979) he hints at the same thing in a very hesitating manner (see below, p. 286). I have expressed my own opinion (above, p. 252) that the Roman citizen, like the dog in English law, 'has a right to his first bite.' See A. C. Clark, Introduction to Cic. Pro Milone, p. xvi.

${ }_{250}$ Strafrecht, p. 69, n. 1. Compare the case of the foreigner in Cicero (De Orat. i. 39, 177) 'cui Romae exulare ius erat.' The point has some interest as refuting Zumpt's supposition that admission to a strange state is in each case a special privilege, for which the Roman noble who has failed to 'keep on the windy side o' the law' would not sue in vain, whereas it would be denied to the vulgar offender. 
his citizenship, but they could (much as in the case of the perduellis described above ${ }^{251}$ ) authoritatively take notice in case of doubt that he had duly deprived himself. Cn. Fulcius exulatum Tarquinios abiit ; id ei iustum exiliums civit esse plebs. ${ }^{252}$ They could decree in like manner that if he did not appear on a certain day videri eum in exilio esse. ${ }^{253}$ Further the case was to be provided against that the man might claim to return, clothed in a new nationality, as a foreigner merely sojourning in Rome; and again it was at least a tenable view ${ }^{254}$ that, if he came back, he would, whether he wished it or not, recover his Roman citizenship by postliminium. All these contingencies were guarded against by the ignis et aquae interdictio. Mommsen is possibly right in believing that this edict was originally a magisterial act applicable at discretion against any foreigner whom it was desired to expel and keep away from Roman territory, and applicable only against foreigners. It would consist in 'his permanent exclusion from the legal protection generally accorded to strangers on Roman ground, and in case of contravention the threat to treat as an enemy him or any one who received or supported him.' ${ }^{255}$ In other words it is 'the decree of magistrate or people, by which the Roman community gets rid of a non-citizen once for all, and forbids him to tread Roman soil on pain of death.' ${ }^{256}$

But, if originally applicable against foreigners, the use of ignis et aquae interdictio is in historical times practically confined ${ }^{257}$ to the case of persons who have once been citizens. Notice was thereby given them that, whether they afterwards denied the fact or not, they were held to have become aliens, and aliens who had been warned off Roman ground. Not only so, but their ceasing to be Romans was anticipated. In the case of Postumius, referred to above, ${ }^{258}$ we find in the event of his not appearing-rideri eum in exilio esse, bonaque eius venire, ipsi aqua et igni placere interdici. This is conditional, but the sentence soon comes to be fulminated directly against persons who are not yet foreigners, sometimes even against those who have no chance of becoming foreigners. It is certainly prescribed for the man who chances to survive the military ' fustuarium ' (see above, p. 233 n. 63), of whom Polybius (vi. $37,4)$ says, ' $H$ is not allowed to return to his country, and none even of his kindred would dare to receive him into their houses.' In all probability the same form of words was used against the victims of the Sullan proscriptions. I am not aware that they

251 See above, p. 260, especially the words, "The effect of the verclict therein pronounced is not condemnatory but declaratory.'

252 Livy, xxvi. 3, 12.

253 Ibid. Ixp. 4, 9.

25. See the interesting case of Publicius Menander in Cicero, Pro Balbo, 11, 28.

253 Strafrecht, p. 72.

254 Ibid. p. 964.

23; Ibid. p. 935.

235 Livy, xxv. 4, 9 .

YOL. XYI.-NO. LXII. 
are ever precisely quoted, for the general term proscriptio acquired a sort of technical sense as a short description of these horrors; but the Greek writers use $\dot{\varepsilon} \kappa \kappa \eta \rho v ́ \sigma \sigma \varepsilon \iota \nu$ or $\dot{z} \pi \iota \kappa \eta \rho \dot{v} \sigma \varepsilon \varepsilon \iota \nu$ indifferently for the action of Sulla or of the triumvirs ( 43 B.c.), ${ }^{259}$ for that of Popillius ${ }^{200}$ against the adherents of Tiberius Gracchus, for that of Saturninus ${ }^{261}$ against Metellus, and for that of Clodius against Cicero. ${ }^{262}$ As regards the more regular action of the law courts Cicero tells us generally (see above, p. 271) that Romans were driven to join a new state ignis et aquae adcmptionc. Augustus describes his action under the 'Lex Pedia' in the words, qui parentem meum interfecerunt, eos in exilium expuli, indiriis legitimis ultus eornm facinus, ${ }^{263}$ whereas Dio Cassius (xlvi. 48) says of their sen-

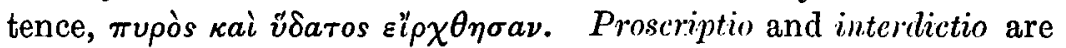
in principle the same thing, and may be equally directed against citizens; many modifications, however, and these of great practical importance, are possible, especially in the extent of territory within which the outlawry is to run, and in the penalties threatened against those who harbour the victims. Sulla's outlawry of the Marians extended over the whole world, leaving no door of escape, and involved all who succoured the fugitives in the same peril. Clodius, whose cruelty Cicero associates with that of Sulla, while threatening like penalties, limited the application of them locally; a local limitation is likewise found in case of the ignis et aquat interdictio which results from condemnation in one of the standing jury courts.

In all cases the state ' makes an open appeal to popular execution of the death sentence' ${ }^{264}$ as the means of enforcing its will ; but it makes a great difference whether the permission to kill is stimulated by reward, as in Sulla's proscriptions, and aided by penalties against those who obstruct it, or whether it is merely left open, so that ' what is everybody's business is nobody's.' Two cases occur in which the 'prohibition of fire and water' seems to be without practical consequences; Oppianicus, condemned for attempt to murder, nevertheless ${ }^{265}$ wanders about in Italy and finally dies in the neighbourhood of Rome, where he has hired lodgings just outside the gate, and $Q$. Pompeius after a condemnation de $v i$ is found living at Bauli, ${ }^{266}$ in the neighbourhood of Naples. It may be noticed that in the first case public opinion held Oppianicus to be an innocent man, who had been condemned by a bribed jury, and in the second that Pompeius had some

${ }^{259}$ For Sulla see Dio Cassius, axxvii. 10, 2 ; for the triumvirs ibid. xlvii. 7,$4 ; 11,3$; 12, 2 ; Appian, Bell. Civ. iv. 14.

${ }^{260}$ Plutarch, Tib. Gracch. 20, and C. Gracch. 4.

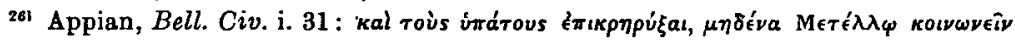

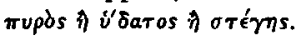

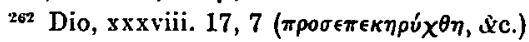

sø3 Mon. Ancyr. 2.

${ }^{265}$ Cic. Pro Clu. 62, 175.

20t Strafrecht, p. 623.

*6 Cic. Ad Fan. viii. 1, 5. 
powerful friends, for Caelius Rufus was able to compel certain fraudulent trustees to do their duty by bim. ${ }^{20 i}$ Under any such favourable circumstances the trespasser on forbidden ground probably ran no great risk. Mommsen remarks ${ }^{268}$

The killing without judicial proceeding of the banished man caught on Roman ground ${ }^{269}$ must have been treated as permitted with impunity rather in theory than in practical application; such a proceeding is irreconcilable with the rule of law, and there are no certain instances of its practical impunity. ${ }^{270}$

Perhaps a practical distinction may be drawn between an inner and an outer circle of territory. The 'Lex Julia Municipalis' describes the exile as iudicio publicy damnatus, quocirca eum in Italia esse non liceret. We find, however, that the tribunes ${ }^{271}$ each year passed a special edict forbidding any person condemned on a capital charge to be in the city of Rome. It is quite possible that they would take active measures against any one who disregarded their own express prohibition, though the wider prohibition of the law, affecting the whole of Italy, might be more of a dead letter.

On the whole, then; we are entitled to say that the ignis et aquae interdictio, as ordained in Sulla's laws, was a death sentence, though one which might be evarled with great ease, and hence the words of his law de capite eius quaerito are fully justified. Mommsen is fairly puzzled with these words, as well he may be.

We must refer them (he says) to the consideration that the "breach of ban' was in fact punished with death, and that so interdictio might be described as a qualified death penalty; and it is further worth wbile to notice that the punishment of treason and murder by simple banishment seemed objectionable, and that on that account choice may have been made of this form of expression, which is at best an astonishing one, and only occurs in this connexion. ${ }^{272}$

This appears but a lame account of the matter, and Mommsen seems irritated at having to admit so much as that interdictio is a qualified death sentence. He speaks elsewhere ${ }^{273}$ of interdictio, ' if

267 Val. Max. iv. 2, 7.

269 There is no English and no Isatin equivalent for the German 'Bannbruch' and 'bannbrüchig,' which occur in almost every sentence of Mommsen's discussion of this topic. The paraphrase must, of course, be so framed as to include both the man who has gone into banishment and come back and the man who has neglected to go at all.

270 Cicero never attempts to plead that the death of Oppianicus cannot be the subject of a criminal charge, because he had no business to be in Italy. But the wide terms of the Lex Cornelia, 'quicunque venenum malum fecerit, vendiderit, emerit, habuerit, dederit' (Pro Clu. 54, 158), would probably have included Cluentius's alleged act, without regard to the quality of the victim, just as (in spite of the 'patria potestas') a father who secretly murdered his son was liable (see the obscure case of Q. Fabius Maximus, Strafrecht, pp. 174, 614, 618). There is no occasion, therefore, to suppose, with Zumpt (Crim.-Proc.p. 466), that the circumstance that Cluentius was stepson to Oppianicus made the difference.

2ii Cic. in Verr. ii. 41, $100 . \quad 272$ Strafrecht, p.907. $\quad{ }^{273}$ Ibid. p. 334, n. 2. 
we are to call that a capital proceeding,' and finally ${ }^{274}$ says downright that 'interdiction under Sulla's legislation can be included under capital punishment only by straining the sense.' I venture to think, on the contrary, that there is no straining of the sense, and no breach of historical continuity, that a iudlicium capitis, throughout the republican period, meant, in the mouth of a lawgiver (whatever it may have meant in the mouth of an advocate), a sentence of death; and that it is a subsequent question, and legally a subordinate one, whether at different epochs the death sentence might be evaded with more or less ease.

That the practical outcome of such a sentence is in Cicero's time in all cases not death but exile (as Polybius says it was already in his own time) is freely admitted; and this consideration is, to my mind, sufficient to account for the fact that exilium is constantly used in a loose way, not only by other writers, but by Cicero himself, ${ }^{275}$ in flat defiance of his own doctrine in the 'Pro Caecina,' as the name of the punishment which the law prescribes for offences. If we tried to bring Cicero to book for his inconsistency he would probably retort on the critics--

Per quos non licet esse neglegentem-

and plead that in the one case he was accurately laying down the legal doctrine of what sentence could be passed on a man, in the other he was equally accurately describing what was likely to happen to the man in consequence.

The innovation introduced by Sulla, or his immediate predecessors, consists not in the death penalty nor in its evasion by exilium-these are an old story-but in the new arrangements necessary to connect this penalty with trial by jury, which was originally invented for a very different purpose. How was this connexion effected? Unhappily there is no answer to be found in the quotations from Sulla's laws which survive; but an answer may be supplied from elsewhere. When Clodius invaded the mysteries of the Bona Dea in 62 s.c. it was found that none of the standing quaestiones were competent to deal with the matter, and that, if it were to be brought before a jury court at all, it must be in virtue of a law passed for the occasion. Two bills were drafted for the purpose, which, however, were precisely the same ${ }^{276}$ except in one detail as to the method of selection of a jury, and the bill of the tribune Fufius, Clodius's friend, was accepted. This is how Cicero describes the procedure: ${ }^{277}$ Familarissimus tuus de te privilegium tulit, ut, si in opertum Bonae Deae accessisses, exulares. The exulares I have already explained-it is a mere short cut anticipating the practical result-there can be no doubt

${ }^{271}$ Strafrecht, p. 909.

${ }^{276}$ Cic. Ad Att. i. 16, 2.
${ }_{275}$ See a number of cases in Strafrecht, p. 966, n. 3. 27 Paradoxa, iv. 32. 
that what the law really said was igni et aqua interdicatur. There was then a sentence of death; though of death easily avoidable, pronounced against Clodius by name. The law was thus a privilegium in that it was directed against an individual, but not a privilegium of the kind forbidden by the Twelve Tables, because it was not an absolute sentence, but one conditional on the finding of a jury. ${ }^{278}$ It was of the nature of legislation, not of a iudicium, and as such it could be passed not only by the Comitia Centuriata, but by any of the assemblies having legislative power. Conditional sentences of the sort against individuals are not without precedent; we have an example in the sentence passed against Postumius by name if he did not appear, ${ }^{279}$ and a similar one is to be found in the decree ${ }^{280}$ passed by the tribunes against Camillus in 367 в.c. : Si M. Furius pro dictatore quid egisset, quingentum millium ei nulta esset. ${ }^{281}$

Now how are we to analyse the part taken by the various actors in the drama of Clodius? The analogy of iudicia ordinaria in private suits ${ }^{282}$ rises at once to the mind. There the praetor in granting his formula utters a sentence, all the force of which comes from his magisterial imperium; but it pleases him to make the falling of this sentence depend on a condition-namely, the finding of a iudex on certain points submitted to him-SI PARET. Within the four corners of his formula the iudex is absolute; he has to find 'yes' or 'no' on whatever questions the praetor has asked him, and his answer is without appeal; but, once he has answered, the effect which that answer is to have is prescribed to him beforehand. ${ }^{283}$ Now in the case of Clodius a part analogous to that of the magistrate in civil suits is played by the people ${ }^{284}$ itself; the people alone can sentence to death; and so it does; but

${ }^{278}$ Cicero (De Domo, 17, 43) lays stress on this point in pleading against the legality of Clodius's proceedings against himself; it is 'poena in cives Romanos nominatim sine iudicio constituta,' which traverses the law of the Twelve Tables, and can only be paralleled by the proseriptions of Sulla.

279 See above, p. 273.

2so Mommsen considers this an invention; certainly Livy, though he found it in some of his authorities, is inclined to disbelieve it. Whether it is true in fact or not it is useful as an illustration of what was considered by early historians to be consti. tutionally possible. See Strafrecht, pp. 882, 1018.

${ }^{281}$ Livy, vi. $38,9$.

282. See Mommsen's reference to the procedure in private criminal cases, above, p. 240 .

${ }^{293}$ Cicero (In Verr. ii. 12, 31) amusingly illustrates the dependence of the 'iudex ' by inventing a burlesque formula, under which the righteous juror would be obliged to be a wheel in the machinery for evolving injustice.

28+ This may seem a hard saying, but I do not mean to ascribe magisterial power to the people, and only say that the use which the people chooses to make of its legislative power here is analogons to that which the magistrate makes of his imperium. This would not appear very strange to a contemporary of Caesar and Cicero, who lived to see the people prescribe in the Lex Rubria exactly what formulae the local magistrate was to issue in each case. 
in the plenitude of its power it chooses to order that a praetor, guided to an authoritative answer by the consilium ${ }^{285}$ of a bench of iudices, shall supply the condition under which alone the sentence is to take effect-SI ACCESSISSES. Once the praetor has pronounced the verdict Fecisse videri the appointed condition has been fulfilled, and the penalty prescribed falls due automatically on the culprit. The dignity of the magistrate is still saved in that the quaestio is his, ${ }^{286}$ and that it is his official utterance which condemns (see above, p. 240); but the punishment is that of the law and not of the magistrate or the jury, so much so that Cicero argues ${ }^{2 \alpha_{i}}$ with logical consistency that the penalty may afterwards be altered by the people which imposed it without in any way infringing the sanctity of the res iullicata. This stops short with the verdict itself, which nothing can reverse. As the people attaches what condition it pleases to the fulfilment of its order, so it regulates all the details of that condition; especially it prescribes how the praetor is to constitute his consilium: the most notable instance, besides this of Clodius, is to be found in the elaborate regulations laid down for the trial of Milo.

The practical result of the introduction of the juror in very early times into civil suits, and the introduction of the jury system at a later period into criminal jurisdiction, is in each case to shift the main responsibility for the decisions arrived at. It is really a devolution of power, a burden taken from the shoulders of the magistrate in civil and of the magistrate and people in criminal trials. But in form the original power and responsibility are always there, and the persons in whom they are vested merely

2si I feel no doubt that the legal position of the jurors alvays is that they are the 'consilium ' of the praetor, though the binding force of their counsel is stiffened by the positive injunction laid on the praetor to pronounce what, after all, is his verdict according as they advise. It is formally a mere matter of detail whether the person who asks advice is free to reject the opinion of his counsellors (as is the general at the head of his army) or is practically bound to abide by it (as is the consul in presence of the senate), or is legally compelled to conform to it (as is the magistrate in a municipium to the decree of the decurions; see Lex Ursonensis, ch. 129). I cannot agree with Mommsen (Strafrecht, pp. 213,443) that 'the retention of their appellation as 'counsellors' is merely a reminiseence, and a respectful presentation of the new position of the magistrate' (see Lex Acilia, vv. 57,60 ; Cic. Ad Att. i. 14, 1, and i. 16,4). Another conjecture of Mommsen (Strafrecht, p. 208), that the presiding magistrate voted along with the jurors as one of his own consilizim, seems to me very improbable in itself and difticult to reconcile with the remarks of Cicero ( In Verr. act. i. 10,32) about Metellus as juror or as praetor : ' malim . . i iurato suam quam iniurato aliorum tabellas committere.' Nommsen's chief argument, from the even number of jurors in the Lex Acilia, loses its force when we consider that the law provides no security that the whole fifty shall vote. After the exclusion of those who said 'amplius' (v. 49) and those who sent in blank tablets (v. 54) it would be purely a matter of chance in each case whether the number of those who gave votes which could be counted proved to be odd or even. We find an actual case of equality of votes which puzzled the praetor in Caelius's letter (Cic. Ad Fam. viii. 8, 3).

ssi Pro Clu. 53, 147. :s7 Pro Sulla, 22, 63. 
choose in their own good will and pleasure to realise them in a complicated and conditional rather than in a simple and direct utterance. A conditional command is as much the expression of the will of the party commanding as a conditional legacy is the expression of the will of the testator.

Though the working of the different parts of the machinery is best seen in the case of a privilegium like that directed against Clodius, the same principles prevail when the people fulminates its death sentence not at an individual, but at a whole category of persons, on every one in fact who has offended, if it can be shown to the satisfaction of a jury that he has so done. The locus classicus in illustration of this is from the First Philippic $(9,23)$. Quid? quod obrogatur legibus Caesaris, quae inbent ei qui de ri itemque ei qui maiestatis damnatus sit, aqua et igni interdici? Quibus quum provocatio datur, noune Cuesaris acta rescinduntur? Now why does granting an appeal in such cases traverse Caesar's Acts? Evidently because the people, on Caesar's rogatio, has already decided what is to be done with such persons. It has sentenced them to death by ignis et aquae interdictio. The condition attached to that sentence has accrued, so soon as the jury find in each case that the man is guilty, and the punishment is bound to follow, as the people has ordered. To ask the people again to decide on the particular case is to ask it to reverse a command which on Caesar's request it has uttered. The people has, in fact, exhausted its powers in the fulmination of the sentence and the creation of the jury court, just as the praetor in civil cases exhausts his powers when he issues the formula to a iudex. If the iudex ordinarius had been a delegate, discharging all the functions of the praetor in his stead, there would under the Roman system have been an appeal from the delegate to the delegator, as was actually the case with the iudex extra ordinem datus of the principate. ${ }^{288}$ But under the formulary system it is otherwise ; the iudex does not act instead of the praetor, but merely supplies information which the praetor happens to want. Thus there can be no appeal; not on the question of fact, for it has pleased the praetor to say that he will take the fact as the iudex finds it ; nor on the question of the consequence, for the praetor has already prescribed what is to follow, and must not be asked to eat his own words. The same principles apply mutatis mutandis to these criminal trials. The law is the utterance of the people, just as the formula is the utterance of the praetor. On the strictest analogy appeal to the people is barred by the existence of a law in which the people's answer is already embodied.

To sum up, the system of capital trials before juries under the regulations of Sulla is that the people by a lex sentences before- 
hand a certain class of criminals to death by outlawry or proscription (ignis et aquae interdictio), making the sentence conditional in each case on the finding of a praetor and jury that a particular man is guilty of the crime in question. When the verdict is delivered the condemned man must hurry away from punishment; he must extinguish his personality as a Roman citizen, thus putting himself under a new jurisdiction, which will not take cognisance of things done in a former state of existence. I cannot express my own view of the effect of exilium better than in Mommsen's words.

Equally with the dead man there is excluded from Roman criminal procedure every man who is severed from the jurisdiction of Rome. Now since every Roman citizen is subject to that jurisdiction, even when he happens to be abroad, and every foreigner is so subject when he happens to be on Roman territory, it follows that the only persons excluded are foreigners who live abroad, and the Roman citizen can withdraw himself from it only if on the one hand he quits Roman soil (solum vertere) and on the other hand attaches himself to some state whose independence is formally recognised by Rome, as a citizen ot in such other way that his reception into it annihilates his Roman citizenship. ${ }^{289}$

Now if, as I believe, this doctrine remains true to the end of the republic, it will follow that the man capitally condemned under Sulla's laws to ignis et aquae interdictio will not be quite safe while he remains a Roman, even outside the local limits assigned to the special ban. $\mathrm{He}$ is still a man capite damnatus, and the state and its officials may, if they please, and if they ean get hold of him without violating neutral territory, execute the death sentence implied in the de capite eius quaerito, though they no longer call on the private citizen to help in the vengeance or threaten penalties on those who succour the convict. It is only by ' casting his old slough' and commencing a new life as a foreigner that he is fully secure. This is never stated totidem ierbis in our authorities, but it is implied in the universal presumption that the condemned man must have taken the course, so necessary to him, ${ }^{290}$ of changing his citizenship. We see, in the passage from the 'Pro Caecina,' that exilium in the sense of deponere ciritatem, not merely of removing beyond the bounds, is the sanctuary-the ara, the portus, the perfugium supplicii which gives security. We find that it is a iustum exilium, of which the people takes note, that it has been performed by $\mathrm{Cn}$. Fulvius. We see Clodius insulting Cicero after his return, ${ }^{291}$ by asking him, Cuius cicitatis es? implying that, as he sees him in a whole skin, Cicero must have

230 Strafrecht, p. 68.

$\approx$ We find much the same sort of presumption in the old comitial trials; it is so obviously the interest of the condemned man to appeal that it is always taken for granted that he has done so (see above, p. 242).

201 De Har. Resp. 8, 17. 
saved it by ceasing to be a Roman, and Cicero ${ }^{292}$ in turn flaunting in the face of his enemy the decree of the senate in which he is described as CIVEM optume de republica nieritum. Cicero's claim is that the whole proceedings against him were null and void, and that he was merely driven away by physical violence; but he would hardly have been 80 anxious to prove, as he does by pages of argument; that he had never ceased to be a Roman, unless it were notorious that a sentence of ignis et aquae interdictio would, as a general rule, compel a man to take the step necessary to divest himself of his former nationality. ${ }^{293}$ Once this is done the only liability for his former misdeeds which remains is that he is obliged to avoid the soil of Italy, which he is forbidden, even as a foreigner, to tread.

As a matter of fact it was probably no great sacrifice to the banished man to surrender his Roman citizenship. $\mathrm{He}$ cannot return to Italy in any case; his political career, if he had one, is ruined. Even if he becomes 'subject to the axe and the rods,' no Roman magistrate is likely to use them against him, and there is some value in the possession of a domicile and a franchise by virtue of which he may claim protection at least when he travels throughout the Roman world, excepting only Italy. We know of one case at least in which such a transformation actually took place. C. Memmius Gemellus, the Memmi clara propago of Lucretius, was condemned in Pompey's sole consulship (52 в.c.), and died apparently before the restoration of the victims of that year by Caesar at the end of 49 B.c. Cicero writes ${ }^{294}$ in the year 46 B.c. recommending to the governor of Achaia a young man, Lyso, quem Memmius, quum in calamitate exilii sui Patrensis civis factus esset, Patrensium legibus adoptarit, ut eius ipsius hereditatis ins causamque tueare. There can be no kind of doubt that Memmius had ceased to be a Roman. There is only one obstacle to our putting his case precisely on the same footing with that of the exile to whom Polybius ascribes 'safety' 'in the city of Tibur -or of Neapolis, or others with which the Romans have a treaty,' and that is that Patrae was not, till after the battle of Actium, a 'free state.' The same difficulty applies in the case of Smyrna, of which Caepio and Rutilius Rufus became citizens. ${ }^{205}$ It may, perhaps, be an answer that, when the Romans renounced the right

$\$ 2$ De Domo, $32,85$.

I venture to think that this is a more legitimate inference than Mommsen's (p.978, n. 1). 'The right of citizenship is, as Cicero often insists, not denied him by Clodius's law, but the ordinary punishment of expulsion from Italy is aggravated by confisca. tion,' \&c. If this were correct Cicero would have had an easy task-only to point out that his case was not worse than that of other 'damnati -whereas his whole contention is that he is not in the same boat with them. What would have been the sense of Clodius's question if the intention of his decree had not been to compel Cicero 'mutare civitatem'?

sos. Ad Fam, xiii, 19, 2

2:5 Cic. Pro Balbo, 11, 28 
of conquest, and restored to any state 'its city, its territory, and its laws' (this is said ${ }^{295}$ of Therma, not a 'free state'), they so far recognised its separate existence as to enable, seu legibus sen muribus, a Roman to be received there with the same effect as if it were technically independent. It is curious, however, that in two out of the three cases the exile is known not to have gone in the first instance to the town which became his eventual home. Rutilius resided at one time at Mitylene, where he was to be found when Mithridates made his great massacre of Romans in 88 B.c. ${ }^{297}$ Memmius certainly was at one time settled at Athens, where he owned the house of Epicurus, ${ }^{298}$ and afterwards at Mitylene. Now if Memmius first became a citizen of Athens there would be no obstacle to his holding the citizenship of Patrae as well; for Cicero tells us ${ }^{2 !} \cdot$ that it was quite possible for a man to be a citizen of two Greek states simultaneously, though he could not hold the citizenship of any Greek state along with that of Rome.

The system, as established by Sulla, underwent no alteration at the hands of Caesar, except that on his proposal the Roman people chose to attach a fresh consequence to condemnation by a jury court-namely, the confiscation of half the goods of the convict. This makes no difference in principle. The people is omnipotent in the matter, and may ordain what consequences it pleases. Under Augustus likewise, though the importance of the jury courts is diminished by the erection of fresh tribunals, with more widereaching powers, nothing is done to alter the situation of such persons as are still brought before the juries. With Tiberius we come to an important change, the results of which are clearly visible in the jurists, though we have only the most meagre account in the history of how they came about. Dio Cassius (lvii. 22) tells us under the year 23 A.D. that 'Tiberius denied to those who were interdicted from fire and water the right to make a will, and this regulation still holds good.' The capacity to make a Roman will is, as Mommsen points out, ${ }^{300}$ ' the most tangible test of Roman citizenship.' When, therefore, we find in a jurist of the third century first ${ }^{311}$ that deportatio in locum ayzae et ignis interdictionis successit, and secondly ${ }^{302}$ meelia capitis deminutio dicitur, per quam sola civitate amissa libertas retinetur, quod fit in en cui aque et igni inter-

2015 Cic. in Verr. ii. 37, 90.

9: Cic. Pro Rab. Post. 10, 27. True he had not at that time renounced his citizenship, for he had to lay aside his toga by way of disguise. Still, as he was not condemnel under in 'capital' sentence, but only for repeturdale, he might choose his time, and may have become a Mitylenean or a Chian before he shifted his quarters to Smyrna.

: Cic. Ad Fan. xiii. 1. To Pro Balbo, 12, 30. 300 Strafrecht, p. 957.

sol Ulpinn, Dig. slviii. 19, 2. The phrases 'igni et aqua interdicere' and 'exilium' remain, however, and are used indifferently with 'deportare;' see Tac. Ann. xii. 4.2, 5 , and xvi. 9, 1 .

so: Ulpian, Reg. xi. 12. 
dicitur, it does not require much ingenuity to piece together the story into a consistent and logical whole.

It appears then that Tiberius wished to sharpen the penalty of ignis et aq"ae interdictio, which resulted from condemnation by a jury, and which was likewise a sentence sometimes pronounced by the senate or the emperor. Sulla and the triumvirs had shown him the way in their proscriptions when they blocked off the exit into the 'harbour and the sanctuary' of exile, and so made the 'capital' sentence effectively one of death. Tiberius did not, however, choose to go as far as this; he took away indeed the old refuge, but provided a new and much less agreeable 'sanctuary' from the executioner. He seized on the person of the convict and deported him to an island, where he was detained a prisoner. By this means exilium was, of course, rendered unavailable; it was no longer physically possible for the condemned man solum. vertere to Massilia or Rhodes, where he could shuffle off his Roman citizenship in exchange for a fresh one, and make a will, if he pleased, under the laws of his new home. So far then his Roman citizenship remains, and if he makes a will it must be by Roman law. But Tiberius did not intend that his victim should retain the Roman citizenship, though he had debarred him from the constitutional means of getting rid of it. He was, therefore, driven to the expedient of taking it away from him by an act of power-applying the solritur ambulando to the impossibility, which Cicero had alleged, of depriving any Roman against his will of citizenship or liberty. The practice of the republic had indeed reduced both impossibilities to little more than legal fictions. It could hand over a thief in chains to work for the man who had caught him, or an insolvent debtor for his creditor; but these men were pro serco, not serri, their technical libertas being untouched, as is shown by their capacity to acquire property by the Roman method of usucapio. ${ }^{30: 3}$ It could in the same way practically deprive a man of citizenship by putting him in such a position that he was obliged to give it up, if he wished to save his throat. ${ }^{304}$ The principate made short work of these niceties. It sent criminals to hard labour for life in the mines and decreed that they were slaves, and (as a slave must have a master) that they were 'slaves of their punishment,' serci pocnae; and in like manner, as a less severe penalty, deported men of rank to an island, and sent mean persons, who were convicted, to 'public works,' in both cases under the loss of citizenship, but with the retention of technical

${ }^{303}$ See Ortolan, Inst. Iustinian. iii. \$ 2027.

${ }^{204}$ Rome got rid of an unwelcome citizen somewhat as Donald M'Aulay in the Legend of Montrose counselled his chief: 'I advised him to put the twa Saxon gentleneen and their servants cannily into the pit $o^{\prime}$ the tower till they gae up the bargain o' free gude-will ; but the Laird winna hear reason.' 
'freedom.' All who underwent this penalty were reduced to a condition analogous to that of the peregrinus decliticius, of whom it is written ${ }^{30.5}$ "that he cannot make a will, either as a Roman citizen, because he is a foreigner, or yet as a foreigner, because he is not the citizen of any particular state, according to whose laws the will can be drawn.' If my presentation be correct, the interlictus down to the time of Tiberius had a right to make a will, not indeed as a Roman, but as a foreigner-' the citizen of some particular state '-and of this capacity he was deprived (as Dio says) by the action of Tiberius.

It is not quite certain whether after the year 23 A.D. ignis et aquae interdictio is always accompanied by deportatio. Ulpian's words (see above, p. 282), deportatio in locum interdictionis successit, seem to indicate an answer in the affirmative. Mommsen ${ }^{306}$ knows no instance to the contrary. On the other hand, as he points out, Gaius ${ }^{307}$ mentions the interdicti and the deportati as two classes of persons who may not make a will. If they are separate, then Tiberius's law, which deprives the convict of Roman citizenship without allowing the possibility of taking up the citizenship of another state, though suggested by the circumstances of the deportatıs, must have been worded so as to cover the other case as well. Probably, however, deportatio is meant to be the fate of every interdictus, and the two categories are mentioned by Gaius only to meet the case of the convict who dies before an island has been assigned for him. ${ }^{308}$ In any case we never again hear of a condemned Roman becoming the citizen of another state.

The universal practice of deportatio is pretty clearly shown by an instructive case mentioned by the younger Pliny. ${ }^{309}$ A certain Licinianus was accused as an accomplice in the incest of a vestal whom Domitian buried alive. In terror at the fate in store for him ad confessionem confugit quasi ad veniam; his counsel announced the plea in words which Hortensius might have used of Verres going to Massilia, ex adlcocato nuntius factus sum: Licinianus recessit. Evidently, however, this retirement into voluntary exile is no longer the end of the matter. Though Domitian exclaims in delight, Absolvit nos Licinianus, and declares that he will not press hardly on him, he is no longer allowed to find refuge on neutral ground. The most the emperor can do for him is to let him plunder his own goods before they are confiscated, and to assign him a pleasant island: exilium molle celut praemium dedit, ex quo tamen postea clementia D. Nervae translatus est in Siciliam. In

305 Ulpian, Reg. xx. 14.

300 Strafrecht, p. 975.

307 Dig. xxviii. 1, 8.

${ }^{305}$ This could be done only by the 'princeps' or 'praefectus urbi,' whereas the sentence of 'ignis et aquae interdictio,' which led to it, might be pronounced by the senate or entailed by the verdict of a jury.

${ }^{309}$ Ep. iv. 11. 
Sicily he lives as an alien, and gives lessons in elocution, dressed in the Greek pallium, carent enin togae iure, quibus igni et aqua interdictum est.

Here, then, we have the most complete picture of the disappearance of the old perfugium supplicii, afforded by the emigration of a Roman to a new home of his choice. The words exilium permitti ${ }^{310}$ are no longer applicable to him. It is no longer possible solum vertere cxilii causa. The phrase has lasted continuously for many centuries. It is applied by Livy to Kaeso. Quinctius and to the decemvirs in the primitive republic: ${ }^{311}$ it. appears in the praetors' edict as quoted in Cicero's earliest speech ; ${ }^{312}$ it is the technical phrase which Cicero interprets in middle life in his general discussion on exile in the 'Pro Caecina,' and he uses it again in his old age after Caesar's death when he says ${ }^{313}$ of Antony's convict jurymen legitimam leabent excusationem. solum vertisse exilii causa. I believe that not only the phrase, but its signification remained unchanged through all these ages, and that it is only with Tiberius that the word and the thing together disappear, and direct deprivation of the citizenship (called equally with physical death a 'capital' punishment) ${ }^{314}$ is substituted for the voluntary putting of it away in a new home. ${ }^{315}$

I have laid stress on what I believe to have been the continuity of the various developments of 'capital' punishment at Rome, because this is one of the few really important points as to which I find myself obliged, with much hesitation and much against my will, to disagree with Mommsen on a matter of legal antiquities. Mommsen believes that there is a great breach of continuity in the history of exilium, and he places this breach at the legislation

310 Sallust, Cat. 51, 22 : 'Alize leges condemnatis civibus non animam eripi sed exilium permitti iubent.' To my mind 'permitti' is the all-important word in this sentence, showing that under Sulla's laws, as earlier, exile was an evasion conceded to the man sentenced to death, conceded by the fact that the law ordered him to be tried under a procedure not admitting of previous arrest. Mommsen, on the other hand (Strafrecht, p. 966), sees in the use of the past tense 'condenunatis' an important distinction between this system and that described by Polybius (above, p. 249). Surely this question of time is but a petty difference. It is difficult to see how Polybius's condition, that the man must go 'before the last tribe has voted,' could be maintained after the ballot was introduced (in 107 s.c.) into comitial trials. At any rate there were jury trials in 'capital' cases before Sulla (Cic. Pro Rosc. Amer. 5, 11; Pro Clu. 55, 151), and the condemned went into exile. Even supposing the change to come into effect only with Sulla's legislation, all that it comes to is that the man is allowed a little more insight into what the verdict is before he has to make up his mind to go; but he has often seen enough before it comes to this. Verres and probably many of the Catilinarians forestalled their sentence by departure.

311 Livy, iii. 13, 9; 58,9. 312 Pro Quinct. 19,60. 313 Philipp. v. 5, 14.

s1t Paulus, Dig. xlviii. 1, 2 : ' per has enim poenas eximitur caput de civitate.'

s1s When Horace remarks $(E p . i .11,17)$ that while a man remains 'incolumis' Rhodes and Mitylene are of no more use to him than a great-coat in the dog-days, he implies that in his time the Roman might still select one of these free states as a shelter if the icy breath of the law overtook him. 
of Sulla. In the introductory book of the 'Strafrecht' he anticipates this conclusion. It will be convenient to quote this passage first, and then to develop his theory by means of extracts from the latter part of the work. The first-named passage (p. 73) is as follows :-

The interdiction of the later law, the relegation out of Italy under penalty for breaking the bounds, which was introduced by Sulla amongst the penalties for citizens, and is wholly distinct in theory and practice from the ancient exilium, will be treated of in the fifth book.

The rolegutio with which this theory starts has already been noted above (p. 235) as a part of magisterial roercitio. It is defined as

the limitation by the authorities of the free choice of a place of residence, whether by a command to leave a certain locality and never more to enter it-that is to say, by expulsion-or by a command to go to a certain locality and not to leave it-that is to say, by internment. ${ }^{316}$

To expulsion in this sense Sulla added, such is the theory, the forbidding of return on pain of death ly the ignis et alumar interlictio hitherto practised only against aliens.

In the legislation of Sulla ${ }^{317}$ it appears as the punishment for treason and murder, and in subsequent penal statutes it was employed in like manner for vis, for ambitus, and for other offences. . . In its essence ${ }^{318}$ Sulla's innovation is not so much that the penalty for transgressing the bounds, which follows of course on all relegation, is raised to the punish. ment of death as that in this manner relegation, which had hitherto been a merely administrative act, is provided with legally. defined local limits, and attached to specific offences, and is thus introduced into the criminal law.... The interdiction ${ }^{319}$ for a term of years or for life (generally unaccompanied by confinement to one place), as Sulla ordained it, and as it was practised until the time of Tiberius, does not alter the man's personal standing; the interdictus retains the citizenship and all the rights that accrue tu it.

Finally, a little lower down (p. 979) Mommsen continues-

We must not disguise the astounding fact that a lawgiver such as Sulla fixed expulsion from Italy, without further legal consequences either for person or for property, as sufficient atonement for the most heinous crimes, even for treason and murder, and treated it as practically the severest criminal penalty. It is possible, however, that supplementary regulations or customs, especially concerning common crimes and offenders of the lower class, ${ }^{320}$ have remained unknown to us; at least it is obvious that the order of proceedings with which we are acquainted has regard especially to offenders belonging to the higher social circles.

Such is the theory: in discussing it the best order will be to begin with relegatio, which I did not notice in my attempt to trace the main lines of development; my reason for this omission is

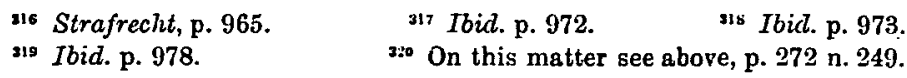


that I believe the simple expulsion of a citizen to be a separate procedure, a strand not inwoven into the system of capital penalties, but running parallel to it throughout the history. Leaving out of account the use of relegatio as a mere method of arbitrary cocrcitio (above, p. 235), there are, so far as I know, only two cases which I should acknowledge as falling under this head in republican times. ${ }^{321}$ The first is that of $\mathrm{M}$. Fulvius Nobilior, relegated in 180 3.c. for a military offence by decree of the senate to a spot, beyond New Carthage, in Spain. In his case the opportunity of exiling himself and changing his state was precluded by. his internment. He would, therefore, retain formally his Roman citizenship, of whatever use that might be to him. The other case is that of persons condemned under Cicero's law de ambitu, who were to be expelled from Italy for ten years. A temporary sentence could never compel a man to renounce his state. ${ }^{322}$ Under the principate relegatio becomes more frequent. and we are better able to measure the gulf which separates it from cxilium or interdictio. The most striking instance of a relegatus is the poet Ovid, who repeatedly lays stress on the distinction. The following lines (Trist. v. xi. 9) may serve as an example:-

Fallitur iste tamen quo iudice nominor exul.

[Caesar] Nec vitam nec opes nee ius mihi civis ademit;

Nil nisi me patriis iussit abesse focis.

Ipse relegati non exulis utitur in me

Nomine.

It is clearly implied here that in the reign of Augustus the ex:ul does lose the rights of a citizen and that the relegatus does not lose them. When, under Tiberius, 'deportation took the place of interdiction from fire and water,' relegation was left just where it was before; it was a comparatively light punishment, which could be inflicted in its original form of simple expulsion from or of internment within the limits of a province by the authority of any governor. The relegatus retains his citizenship and his right to make a will, whereas the deportatus loses them. Since, then, the opposition hetween exul and relegatus which we see in Ovid is continued in the opposition between deportatus and relegatus, it seems only reasonable to conclude that ignis et aquae interdictio, ${ }^{323}$ which forms

321 Livy, xl. 41, 10, and Dio Cass. xxxvii. $29,1$.

322 The rule held under the principate, when condemnation for a term of years to the mines or to 'deportatio' did not act as depriving the eriminal of liberty or of citizenship respectively, as such a sentence did when inflicted for life; Dig. xlviii. 19, 28, 6. That Cicero sometimes calls even the temporary penalty 'exilium' (e.g. Pro Afurena, 23, 47, and 41, 89) is only a loose and popular way of speaking. Ovid of course does the same in pathetic descriptions of his own fate, though the lines quoted in the text show that he knew that the expression was incorrect.

323 Though the verb 'interdicere' (not 'igni et aqua interdicere') in a general 
the connecting link between exilium and deportatio, is equally opposed to relegatio.

The issue between Mommsen's theory and what I understand to be the obvious interpretation of ignis et aquae interdictio under Sulla's ordinances may perhaps appear to be largely a question of words. It is agreed on both hands that the man is liable to be put to death if he does not leave Italy, or if, having left, he comes back again; likewise that if he goes away and keeps away he will not in practice be put to death. It does not seem to make much difference whether we say ' he is sentenced to leave Italy on pain of death' or ' he is sentenced to be put to death if he does not retire from Italy.' Nommsen puts it in the one way for all offenders but one, and in the other way for the parricide; yet the result for all is alike, so far as the avoidance of death is concerned. The reason for preferring the second form is that it agrees with the logical order of ideas as presented by Cicero in the 'Pro Caecina,' and likewise with the practice of the second century B.c. as related by Polybius. In both we find that the threat of death comes first, and the evasion of it by self-banishment follows, not that a sentence of banishment comes first, with the threat of death to follow if banishment be evaded.

But the important question is whether this retirement (commanded, as Mommsen would maintain, permitted, as I should prefer to say, with Sallust ${ }^{324}$ ) is a mere physical removal, or whether it further implies some act by virtue of which a man ceases to be a Roman. As it is beyond dispute that before Sulla and after Tiberius the exul ceases to be a citizen, the burden of proof lies heary on the interpreter who maintains, in spite of the complete silence of our authorities as to any change, that a different theory and practice obtained in the intervening period. What, then, is the proof of the proposition that in the interval between Sulla and Tiberius a Roman condemned on a 'capital' charge retained his Roman citizenship? I know of only two pieces of purely circumstantial evidence. The first is ${ }^{325}$ that the young Oppianicus, upon the death of his father, a man convicted of poisoning, is found to be owner of Nicostratus, one of his father's slaves. ${ }^{326}$ The elder Oppianicus must therefore, Mommsen argues, have been capable of bequeathing property. Possibly; but that does not tell us under the laws of what state Uppianicus's will was made. Mommsen assumes that it was under Roman law, and that therefore Oppianicus was a Roman citizen; but he may very well, after his condemnation, have slipped across the Straits of

sense for 'forbidding a particular place' is frequently used in connexion with simple expulsion. See Dig. xlviii. $22,7$.

22+ See above, p. 285 n. 310.

3Es Strafrecht, p. 978.

${ }_{326}$ Cic. Prọ Clu. 68, 176. 
Messana and obtained a domicile as a citizen of one of the foederatae civitates of Sicily. In that case he would make his will according to the laws of Messana or Tauromenium; a legacy under such an instrument would pass the slave to his son, just as well as a legacy under a Roman will.

The second instance adduced by Mommsen in the same place requires more discussion. In the 'Lex Iulia Municipalis,' verse 118, we find amongst those who are disqualified for municipal ffice queive iudicio publico Romae condemnatus est erit, quocirca eum in Italia esse non liceat. This, says Mommsen, would be unnecessary if the condemned man was no longer a citizen. Supposing this to be granted, I think it by no means follows that what was unnecessary could not have found a place in the clauses of a law. The Romans were fond of legal verbiage and of heaping up precautions, sometimes against what was already really barred ${ }^{327}$

I do not, however, feel quite so sure that it was unnecessary. The clause is a repetition, as applied to the municipal senates, of what Cicero tells us ${ }^{328}$ was the rule at Rome-Ubi caristi ne meo loco censor in senatum legeret? quod de onnibus, etiam quibus damnatis interdictum est, scriptum est in legibus. ${ }^{329}$ Now, as we have seen, it was very difficult to prove the animus cxulandi which was essential to the mutatio ciritatis ; and this might have led to awkward consequences. Suppose that Milo had written to say that he was eating mullets certainly at Massilia, where Roman law could not touch him, but that he had no intention of becoming a Massiliot; might not the next censor, by way of demonstrating his political sympathies, ${ }^{330}$ have placed his name on the senatorial roll? Marcius Philippus felt doubt as to passing over his uncle, Appius Claudius, who was a victim of some political trial in the Marian troubles; ${ }^{331}$

32: There is an instance in the Lex Acilia. Verse 22 prescribes that the accuser, in naming his hundred 'iudices' out of the 'album,' is not to choose any magistrate or senator, whereas such choice is already abundantly provided against by the circum. stance that senators are by verse 16 already excluded from the list out of which the choice is to be made. Zumpt (Crim.-Recht, rr. i. 125) rather than admit such a superfluity takes refuge in the absurd supposition that these ' iudices' were not selected from the 'album,' but from outside. He supplies us with a useful object lesson as to the danger of arguing in this way.

328 De Donno, si, 82.

${ }^{320}$ Exclusion is mentioned as the result of conviction in certain cases in the Lex Acilia, verse 13-' queive quaestione ioudiciove puplico condemnatus siet quod circa eum in senatum legei non liceat.' Yet persons condemned in Gracchus's time for murder or conspiracy, whether they were tried by special commissions or by standing jury courts, must certainly have ceased to be Romans. We find the same disability specially imposed by a Lex Cassia of 104 B.c. on persons condemned by the people (see Strafrecht, p. 1000).

${ }_{330}$ If $\mathrm{I}$ mistake not, it was proposed in an Irish constituency to elect as member of parliament a Fenian convict, still in gaol ; and his supporters only desisted when they found that votes given for the convict would be simply thrown away, and that his competitor could claim the seat on a scrutiny.

${ }^{331}$ De Domo, 32, 84.

VOL. XVI. -No. LXII. 
and of Cicero himself Cotta swore that if his censorship had been contemporaneous with Cicero's exile he would have 'read out his name' in his proper place notwithstanding. If it were prudent to guard against this at Rome it would be even more necessary in a municipium, where the convict might well be a person of local importance and popularity. It was the policy of the Romans to avoid any such controversies by positive prohibitions under penalty, and further by heaping ignominia on the heads of persons convicted, to heighten the inducement to get out of it all by renouneing their country. Yet another point may be noticed. The phrase quocirca eum in Italia esse non liceat will cover more cases than ' capital ' ones. A man condemned under Cicero's law de ambitu would be in this case ${ }^{332}$ for the next ten years; yet no one supposes that he ceased to be a Roman, and so if Caesar wished to exclude him from a town council he would be obliged to declare him ineligible under some such clause as this. On the whole then I think that we cannot say that this clause of the 'Lex Iulia Municipalis ' proves anything decisively against the proposition that the man actually condemned under a capital charge before a jury, like the man on the point of condemnation before the comitia, was in a position in which it was so obviously needful for him to change his state that the law assumed ${ }^{33}$ that he had done so.

Thus the evidence for Mommsen's theory seems to crumble away, while the objections to it remain unanswered. Mommsen is obliged to ignore Cicero's elaborate exposition of the true doctrine of exilium in the 'Pro Caecina.' How could Cicero have dared to proclaim in open court that 'in no law of ours is any crime punished by exile, as it is in other states,' unless he had been sure that his hearers recognised that the banishment, which, when he spoke, was notoriously the result of conviction, was not inflicted by direct sentence of the law (as it was in the case of relegatio), but was brought about indirectly by the effect which the fear of consequences produced on the will and the choice of the convict? Where,

$\$ 232$ It is pretty clear from the peroration of Cicero's speech that Murena, if condemned, must have quitted Italy, not only Rome. I see no reason for supposing that the penalty was otherwise than a temporary one when the Lex Iulia was enacted, in 46 в.c. Mommsen, incieed, thinks (p. 874) that Pompey in his sole consulship made the banishment permanent. There is no evidence, however, that the 'heightened penalty' ascribed to Pompey's legislation lasted longer than trials before the special courts of the year 52 B.c.

${ }^{333}$ On the otiner hand a man who lay under no such necessity, but who had through ignorance performed acts which properly involved renunciation of Roman citizenship, was relieved from these consequences; see Cic. Pro Balbo, 12, 30 : - Quo errore ductos vidi egomet nonnullos imperitos homines, nostros cives, Athenis in numero indicum atque Areopagitarum certa triba, certo numero; quum ignorarent, si illam civitatem essent adepti, hanc perdidisse, nisi postliminio recuperassent.' Here evidently the law argues, from the absence of need, that the man was only masquerading and had really no 'animus exulandi,' so he does not actually become an Athenian or lose his Roman franchise. 
again, if we accept Mommsen's hypothesis, are we to find the point of Clodius's taunt when he asked Cicero to what state he belonged? or how shall we account for Memmius adopting an heir under the laws of Patrae? ${ }^{334}$ or what sense are we to make of Ovid's insistence that he, unlike a real exul, has never lost the rights of a citizen ? Above all, how are we to explain the de capite eius quaerito of Sulla's law, which Mommsen finds 'astonishing,' but which appears to me to be absolutely crushing to his theory? For it is impossible to escape from this by the plea of rhetorical exaggeration. Advocates from Lucius Crassus downwards ${ }^{335}$ play so freely not only with caput, but with vita and sangnis, that there is no difficulty in conceding Mommsen's assertion that 'the Roman who is not allowed to tread the soil of Italy is in the language of the orators no Roman at all.' ${ }^{336}$ But all this is beside the mark; we have here to do not with the metaphors of a pleader but with the calm and matter-of-fact language of a law; when the ipsissima verba of a statute read de capite quaerito, surely these words must be taken to mean what they say. In presence of all these considerations ${ }^{33 i}$ not even the authority of Mommsen can convince me that Sulla introduced any new-fangled principle into 'capital ' trials. On the contrary I believe that the principle remains the same throughout, and that the successive applications of it develop regularly and logically out of one another from the time of king Tullus Hostilius to the time of the emperor Tiberius. If we hold fast to this doctrine we are really following the spirit of what Mommsen has taught us; we remove what is only an excrescence from his general presentation of the Roman criminal law, and restore consistency to the splendid and orderly whole which his genius has evolved out of the chaos of conflicting evidence.

I have now gone through the principal questions which lie along the main lines of the history of the Roman criminal law. To enter into any by-paths of discussion, however interesting, is impossible within the limits, already most generously extended for me, of an article in this Review. I can only end, as I began, by expressing my deep sense of the thanks due by the student of Roman history to the author of this great work.

\section{J. L. Strachan-Davidson.}

\footnotetext{
134 I do not think that it is pure accident that the Romans mentioned in the Pro Balbo $(11,28)$ as having become citizens of other states all belong to a past generation, but still less do I think that Cicero could find no cases in his own time. The silence is due, I think, to the circumstance that living men could not with politeness be reminded of the 'calamitas exilii sui.'

${ }^{355}$ Cic. De Orat. i. 52, 225.

33; Strafrecht, p. 978, n. 2.

237 See above, pp. 270, 275, 280, 281, 287.
} 